\title{
Article \\ Effect of Lactobacillus plantarum Biofilms on the Adhesion of Escherichia coli to Urinary Tract Devices
}

\author{
Fábio M. Carvalho, Rita Teixeira-Santos, Filipe J. M. Mergulhão $\mathbb{D}$ and Luciana C. Gomes *(D) \\ LEPABE—Laboratory for Process Engineering, Environment, Biotechnology and Energy, Faculty of Engineering, \\ University of Porto, Rua Dr. Roberto Frias, 4200-465 Porto, Portugal; up201502963@fe.up.pt (F.M.C.); \\ ritadtsantos@fe.up.pt (R.T.-S.); filipem@fe.up.pt (F.J.M.M.) \\ * Correspondence: luciana.gomes@fe.up.pt; Tel.: +351-22-041-3603
}

Citation: Carvalho, F.M.;

Teixeira-Santos, R.; Mergulhão, F.J.M.; Gomes, L.C. Effect of Lactobacillus plantarum Biofilms on the Adhesion of Escherichia coli to Urinary Tract Devices. Antibiotics 2021, 10, 966. https://doi.org/10.3390/

antibiotics10080966

Academic Editor: João Vilares Neves

Received: 1 July 2021

Accepted: 7 August 2021

Published: 11 August 2021

Publisher's Note: MDPI stays neutral with regard to jurisdictional claims in published maps and institutional affiliations.

Copyright: (c) 2021 by the authors. Licensee MDPI, Basel, Switzerland. This article is an open access article distributed under the terms and conditions of the Creative Commons Attribution (CC BY) license (https:// creativecommons.org/licenses/by/ $4.0 /)$.

\begin{abstract}
Novel technologies to prevent biofilm formation on urinary tract devices (UTDs) are continually being developed, with the ultimate purpose of reducing the incidence of urinary infections. Probiotics have been described as having the ability to displace adhering uropathogens and inhibit microbial adhesion to UTD materials. This work aimed to evaluate the effect of pre-established Lactobacillus plantarum biofilms on the adhesion of Escherichia coli to medical-grade silicone. The optimal growth conditions of lactobacilli biofilms on silicone were first assessed in 12-well plates. Then, biofilms of L. plantarum were placed in contact with E. coli suspensions for up to $24 \mathrm{~h}$ under quasi-static conditions. Biofilm monitoring was performed by determining the number of culturable cells and by confocal laser scanning microscopy (CLSM). Results showed significant reductions of $76 \%, 77 \%$ and $99 \%$ in E. coli culturability after exposure to L. plantarum biofilms for 3, 6 and $12 \mathrm{~h}$, respectively, corroborating the CLSM analysis. The interactions between microbial cell surfaces and the silicone surface with and without L. plantarum biofilms were also characterized using contact angle measurements, where E. coli was shown to be thermodynamically less prone to adhere to $L$. plantarum biofilms than to silicone. Thus, this study suggests the use of probiotic cells as potential antibiofilm agents for urinary tract applications.
\end{abstract}

Keywords: biofilm; probiotic; Lactobacillus plantarum; antibiofilm activity; urinary tract devices; Escherichia coli

\section{Introduction}

Biofilms, defined as communities of microorganisms attached to inert or living surfaces and surrounded by a self-synthetized matrix of extracellular polymeric substances, are a form that microbes adopt to expand metabolic cooperation and gain protection from hostile environmental conditions, such as immune responses and antimicrobial treatments [1,2]. This constitutes a challenge in treating biofilm-associated infections and is particularly severe since the presence of biofilms accounts for about $80 \%$ of human microbial infections $[3,4]$. Bacteria in biofilms are often hard to eradicate by antibiotics, the continuous administration of which leads to high rates of antibiotic resistance by pathogens [5].

Healthcare-associated urinary tract infections (UTIs) have a prevalence ranging from $13 \%$ in the USA and $20 \%$ in Europe, to up to $24 \%$ in developing countries [6,7], due to the common insertion of invasive urinary tract devices (UTDs), including urinary catheters and urethral stents [8,9]. UTIs have a great impact on patients' safety and healthcare systems, causing high morbidity and mortality, increased hospitalization periods, and costly treatment [10-12]. UTDs are typically made of polymeric materials which, despite their attractive mechanical properties, are intrinsically prone to microbial adhesion and consequent biofilm development [13]. Additionally, the innate defense mechanisms of the urinary tract system might be weakened when a UTD is placed, making the microorganisms in the lumen of UTDs less susceptible to phagocytosis or the action of antimicrobial agents [4]. The majority of these infections are caused by Escherichia coli, Klebsiella 
pneumonia, Pseudomonas aeruginosa, Staphylococcus aureus, Enterococcus faecalis, and Proteus mirabilis [14-16]. However, E. coli has been described as the most common pathogen in short-term UTD biofilms, being able to invade and persist as biofilm-like aggregates inside bladder superficial cells [17].

In recent years, many advances have been made in the development of effective antimicrobial therapeutics to reduce the incidence of UTD infections. Novel strategies to prevent biofilm formation on UTDs include antimicrobial agents' release, contact-killing, the inhibition of microbial adhesion, and disruption of the biofilm architecture [18,19]. However, although these approaches were shown to prevent adhesion and biofilm formation in the medical field, questions relating to bacterial resistance, cytotoxicity, biocompatibility, and long-term efficacy during catheterization require more extensive validation in future studies [11,19].

Probiotics were recently introduced as an interesting option to inhibit or delay the onset of biofilm formation in medical devices [20]. The activity of probiotics and/or their isolated metabolites against medical device-associated infections, including UTDs, was recently reviewed [21-23]. Probiotics are beneficial live microorganisms that, when ingested in sufficient numbers, produce health benefits for the host [24]. They are commonly known as non-pathogenic friendly bacteria and have received substantial attention because of their health-promoting properties, particularly in the digestive tract and immune system, possessing GRAS (generally regarded as safe) status [25]. The most commonly used probiotics are various species of lactic acid bacteria (LAB), which include Lactobacillus, Bifidobacterium, Streptococcus and Lactococcus [26,27]. Lactobacillus is one of the most important groups of the LAB genus [28]. It comprises a large heterogeneous group of Gram-positive, nonsporulating and facultative anaerobic or microaerophilic rod-shaped bacteria, including Lactobacillus acidophilus, Lactobacillus casei, Lactobacillus fermentum, Lactobacillus plantarum, and Lactobacillus rhamnosus [29,30]. They are nutritionally fastidious, requiring rich media to grow [31]. Metabolically, LAB are known to produce lactic acid as a major end-product of carbohydrate fermentation and other metabolites [32-34]. The selection of probiotic organisms requires a systematic approach to infer their functional and beneficial properties. It is necessary to consider their ability to adhere to surfaces, produce inhibitory substances, and survive and grow under adverse conditions [31,33,35]. The effectiveness of probiotics is strain-specific, and each strain has multiple and diverse impacts on the host through different mechanisms [36]. These mechanisms include the production of antagonistic substances that generate a physiologically restrictive environment for pathogens, competition for surface area and nutrients, biofilm formation, and the prevention of quorum sensing (QS) [37-39].

Despite promising results in displacing adhering uropathogens and inhibiting bacterial adhesion to catheter materials [40-48], the application of probiotics as a coating for UTDs remains barely explored. Since bacterial adhesion and biofilm growth are affected by the hydrodynamic forces around surfaces [49], and these forces vary between the upper and lower urinary tract, as well as on the inner and outer part of the device, it is important to consider this variability when setting an experimental assay of biofilm formation [9]. The experiments should also use biologically relevant fluids like pooled human urine or artificial urine [9]. Most of the antibiofilm assays are performed under static conditions [40,43-46], characteristic of the extraluminal side of UTDs [9], while just a small number of studies used the controlled hydrodynamic conditions [47,48] from intraluminal surfaces in the urethra, bladder or ureter [9]. On the other hand, only a couple of studies used nutritional conditions similar to those found in human urine $[47,48]$.

Hence, the present study aimed to optimize the biofilm-forming capacity of a probiotic strain, Lactobacillus plantarum, and evaluate the ability of L. plantarum biofilms to prevent E. coli biofilm formation on silicone rubber. Additionally, the thermodynamic propensity of E. coli to adhere to silicone rubber with and without L. plantarum biofilms was determined. To the best of our knowledge, this is the first study using pre-formed probiotic biofilms to prevent the biofilm formation of pathogens, combining the effect of temperature, device 
surface, and nutritional and hydrodynamics conditions that mimic a specific urinary tract region. In this way, we have used more realistic conditions in order to increase the predictive value of this work.

\section{Results}

\subsection{Biofilm-Forming Capacity of L. plantarum}

The ability of L. plantarum to adhere and form biofilms on silicone coupons was first evaluated by combining different hydrodynamic, nutritional, and temporal conditions. L. plantarum demonstrated a remarkable ability to adhere and establish biofilms on silicone (Figure 1). Looking at the effect of incubation time, cell culturability (Figure 1a) and biomass amount (Figure 1b) decreased over time, regardless of the growth medium and hydrodynamics. Biofilms that formed under static conditions presented significantly higher biomass amounts than those grown under high shaking conditions $(p<0.05$; Figure $1 \mathrm{~b})$. Furthermore, L. plantarum biofilms formed in De Man, Rogosa and Sharpe (MRS) broth exhibited higher culturability and biomass than those formed in artificial urine medium (AUM).

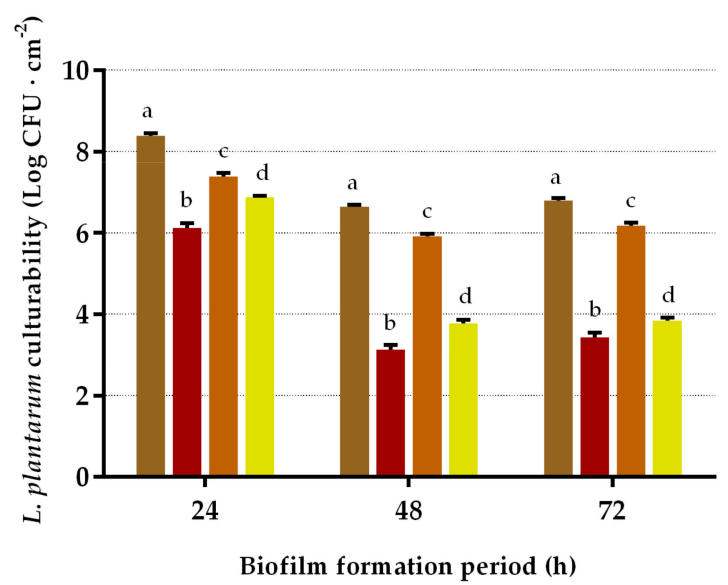

MRS broth - Static

(a)

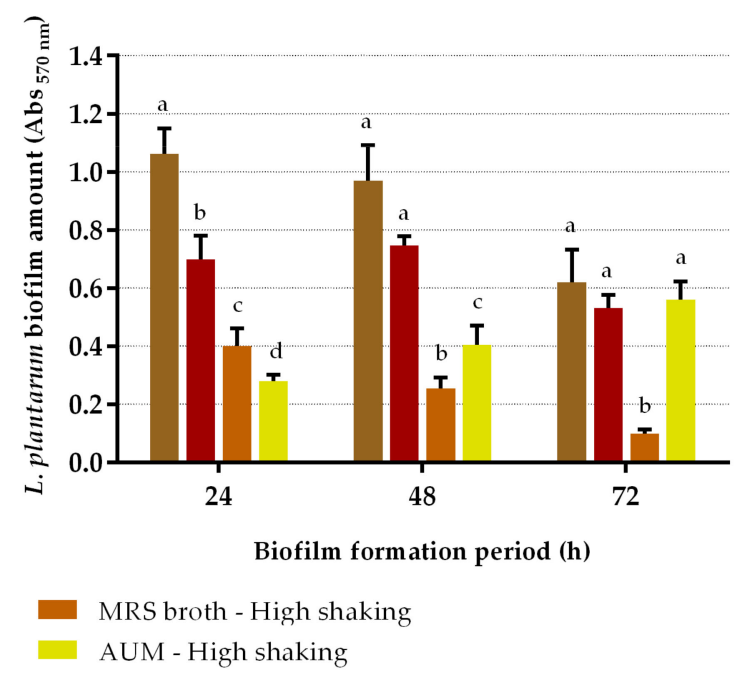

(b)

Figure 1. Culturability (a) and total biomass (b) of L. plantarum biofilms after 24, 48 and $72 \mathrm{~h}$ of development. Biofilms were formed on silicone in two different media (AUM and MRS broth) and at two hydrodynamic conditions (static and high shaking conditions). The data shown represent the mean and standard deviation (SD) of at least three independent experiments. Different lower-case letters indicate statistically significant differences between the same biofilm formation times $(p<0.05)$.

Then, a second screening was performed using MRS broth under different hydrodynamic and temporal conditions, replacing the culture medium every day to ascertain any possible nutritional limitations. As regards biofilm cell culturability (Figure 2a), it can be observed that it significantly increased over time $(p<0.05)$, regardless of the hydrodynamic condition, reaching the highest culturability levels after $72 \mathrm{~h}$ of incubation under quasi-static conditions, with $8.29 \pm 0.05 \log \mathrm{CFU} \cdot \mathrm{cm}^{-2}$. Comparing the effect of agitation on biofilm formation, biofilms that formed under quasi-static conditions presented higher culturability values than those grown under more intense orbital shaking conditions $(p<0.01)$. The values ranged from $7.84 \pm 0.12$ to $8.29 \pm 0.05 \log \mathrm{CFU} \cdot \mathrm{cm}^{-2}$ (with an average value of $8.06 \log$ CFU. $\mathrm{cm}^{-2}$ ) for quasi-static conditions, and between $6.37 \pm 0.07$ and $7.73 \pm 0.06 \log$ CFU. $\mathrm{cm}^{-2}$ (with an average value of $7.17 \log \mathrm{CFU} \cdot \mathrm{cm}^{-2}$ ) for high shaking conditions. The results of biomass analysis were generally in agreement with those of culturability (Figure $2 b$ ). The Abs $570 \mathrm{~nm}$ values ranged from $0.56 \pm 0.07$ to $0.74 \pm 0.03$ for quasi-static conditions, and between $0.16 \pm 0.02$ and $0.61 \pm 0.03$ for high shaking conditions. 
There was an increase in biofilm biomass over time for both hydrodynamic conditions; however, for low agitation, the differences were not statistically significant $(p>0.05)$. These results allowed us to draw conclusions about the ideal conditions needed for the growth of robust $L$. plantarum biofilms to cover the silicone surfaces in the antibiofilm assays against E. coli. Although the culturability of $72 \mathrm{~h}$ biofilms was slightly higher than that of $48 \mathrm{~h}$ biofilms ( $8.29 \pm 0.05$ versus $\left.8.04 \pm 0.13 \log \mathrm{CFU} \cdot \mathrm{cm}^{-2} ; p=0.012\right)$, the biomass amount was very similar (Abs $570 \mathrm{~nm} 0.74 \pm 0.03$ and $0.74 \pm 0.23$, respectively; $p=1.000$ ). Thereby, in further assays, L. plantarum biofilms were formed for $48 \mathrm{~h}$ in MRS broth under quasi-static conditions with medium replacement.

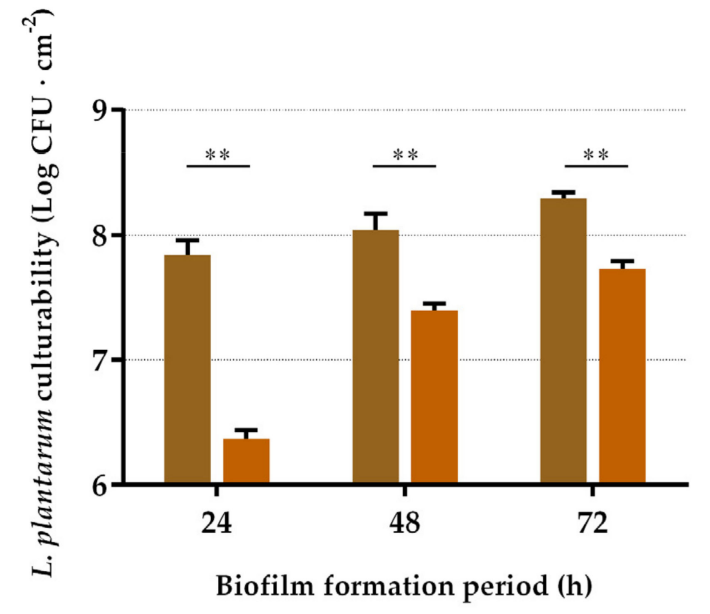

(a)

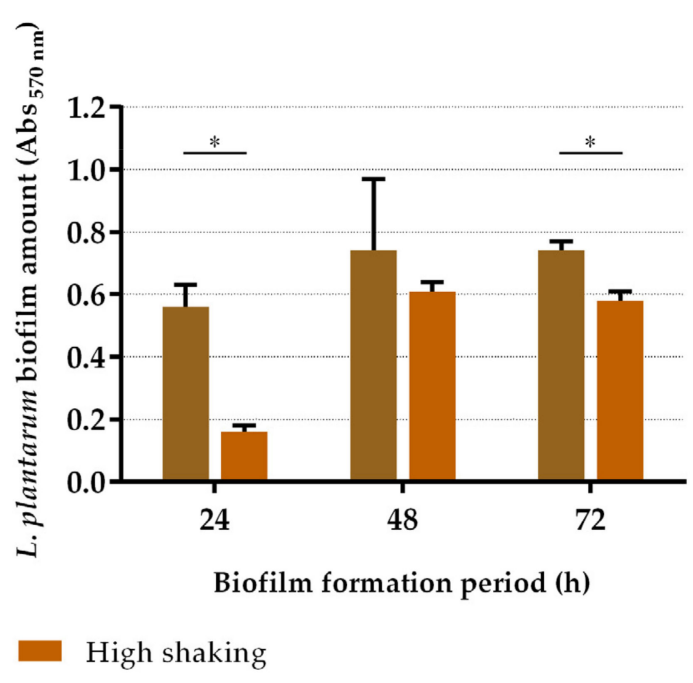

(b)

Figure 2. Culturability (a) and total biomass (b) of L. plantarum biofilms after 24,48 and $72 \mathrm{~h}$ of development under quasi-static and high shaking conditions. Biofilms were formed on silicone coupons in MRS broth with medium replacement every day. The data present the mean and standard deviation (SD) of at least three independent experiments. Statistically significant differences between quasi-static and high shaking conditions were considered for $p$-values $<0.05{ }^{*}$ and ${ }^{* *}$ indicate $p<0.05$ and $p<0.01$, respectively).

\subsection{Antibiofilm Assays}

Having established the ideal conditions for biofilm formation, we proceeded to evaluate the ability of pre-established L. plantarum biofilms to inhibit the early development of E. coli biofilms. The results of culturable cells of E. coli and L. plantarum after 3, 6, 12 and $24 \mathrm{~h}$ of incubation are presented in Figure 3. As can be observed in Figure 3a, the number of E. coli culturable cells was significantly reduced over time when exposed to L. plantarum biofilms, in comparison to bare silicone $(p<0.001)$. Reductions of $76 \%$ and $77 \%$ were obtained after 3 and $6 \mathrm{~h}$ of incubation, respectively. The highest decrease in E. coli biofilm formation was achieved after $12 \mathrm{~h}$ of exposure, with a reduction of $99 \%$, this being the most promising experimental time. However, when the contact between the bacterial strains was prolonged for $24 \mathrm{~h}$, the ability of L. plantarum biofilms to inhibit the colonization of E. coli started to decrease (percentage of reduction: $60 \%$ ). The culturability of L. plantarum in biofilms was also evaluated (Figure $3 \mathrm{~b}$ ) and the results showed a significant decrease over time, being more pronounced at 12 and $24 \mathrm{~h}$ with a $99.9 \%$ reduction when compared to control $(p<0.001)$. The presence of L. plantarum on the dual-species biofilms remained dominant during the first $6 \mathrm{~h}$, where L. plantarum represented approximately $95 \%$ of the total biofilm population. However, after $12 \mathrm{~h}$ of contact, there was a marked decrease in the quantity of L. plantarum culturable cells in the biofilm. 


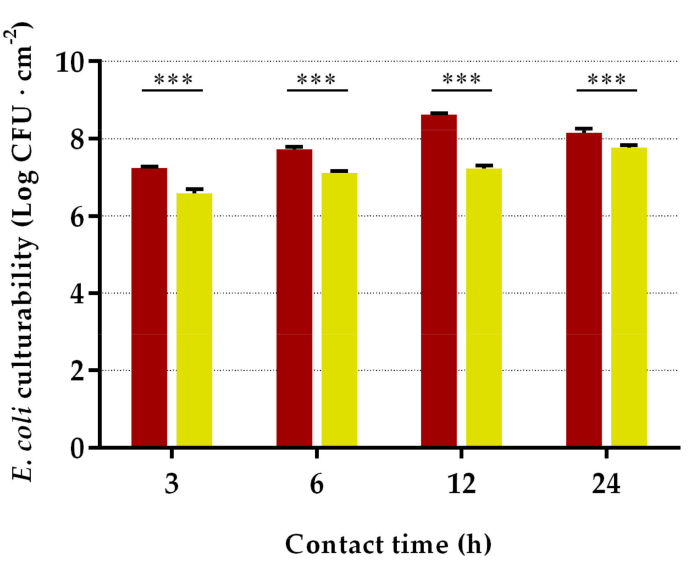

E. coli biofilm (control)

L. plantarum biofilm + E. coli

(a)

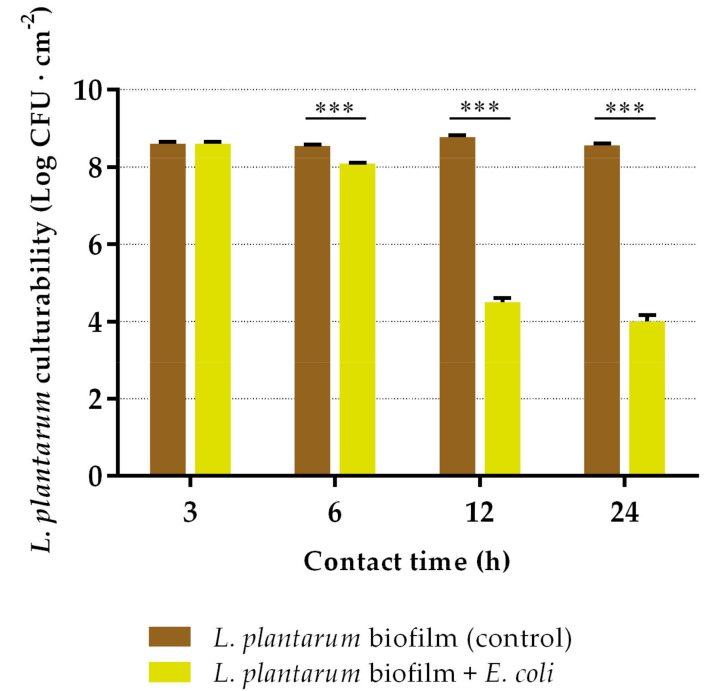

(b)

Figure 3. Culturability of E. coli (a) and L. plantarum (b) after 3, 6, 12 and 24 h of contact between the pre-formed probiotic biofilm and the pathogen. The biofilms of L. plantarum were formed for $48 \mathrm{~h}$ on silicone coupons under quasi-static conditions in MRS broth at $37^{\circ} \mathrm{C}$ with medium replacement. E. coli was subsequently added to the wells for 3, 6, 12 and $24 \mathrm{~h}$ under quasi-static conditions in AUM at $37^{\circ} \mathrm{C}$. The culturability of L. plantarum and E. coli cells in the biofilm was determined by colony-forming units (CFU) counts. The data present the mean and standard deviation (SD) of at least three independent experiments. Statistically significant differences between the control and exposure were considered for $p$-values $<0.05(* * *$ indicates $p<0.001)$.

In order to observe the spatial distribution and the heterogeneity of E. coli and L. plantarum populations in single- and dual-species biofilms, a confocal laser scanning microscopy (CLSM) analysis was performed after 12 and $24 \mathrm{~h}$ of exposure (Figure 4 ). The representative confocal images (Figure 4a) showed a marked reduction of E. coli colonization in dual-species biofilms, compared with E. coli single-species biofilms. In fact, while bare silicone surfaces were covered by dense E. coli biofilms (especially after $24 \mathrm{~h}$ of exposure, with a surface coverage of approximately $90 \%$ ), only a few single cells of E. coli, heterogeneously distributed, were observed in the presence of L. plantarum biofilms. Looking at the vertical profiles of L. plantarum + E. coli biofilms (Figure 4b), these few bright cells of E. coli expressing green fluorescent protein (GFP) were mainly located in the interior regions of the biofilms, near the bottom, while L. plantarum cells (marked in red) were positioned all over the biofilm. This was confirmed by the quantitative results extracted from the $z$-stack acquisition (Figure 4c), which showed that E. coli cells that emitted the green signal occupied the bottom layer of the biofilm. This suggests that E. coli tends to penetrate the pre-established biofilms of L. plantarum and lodge at the bottom of the biofilm. Moreover, although mixed biofilms are mostly composed of L. plantarum (Figures 3-5), the presence of empty spaces (black regions) in dual-species biofilms could be observed, in contrast to the dense single-species biofilms of L. plantarum covering the silicone surfaces (Figure 4a), corroborating the culturability results obtained for both bacteria.

Regarding the quantitative CLSM analysis, L. plantarum biofilms significantly reduced the biovolume of E. coli by $95 \%$ at 12 and $24 \mathrm{~h}(p<0.01$; Figure 5a). Conversely to Figure $3 b$, where there was a decrease in the culturability of L. plantarum from single- to dual-species biofilm at $12 \mathrm{~h}$, in Figure $5 \mathrm{~b}$ the biovolume of L. plantarum at $12 \mathrm{~h}$ showed no significant differences between the control and exposure groups $(p=0.564)$. Likewise, the biovolume of L. plantarum in single-species biofilms at $24 \mathrm{~h}$ was higher than at $12 \mathrm{~h}$ ( $p=0.064$; Figure 5b), while no differences were found in culturability between the same samples (Figure 3b). The biofilm thickness was also assessed (Figure 6). The thickness of dual-species biofilms was reduced from $96 \mu \mathrm{m}$ at $12 \mathrm{~h}$ to $64 \mu \mathrm{m}$ at $24 \mathrm{~h}(p<0.001)$. On the other hand, the thickness of single-species biofilms of L. plantarum was maintained at 
approximately constant $(p=0.584)$, and the thickness of single-species biofilms of $E$. coli increased from $24 \mu \mathrm{m}$ to $39 \mu \mathrm{m}$ between 12 and $24 \mathrm{~h}(p<0.01)$.

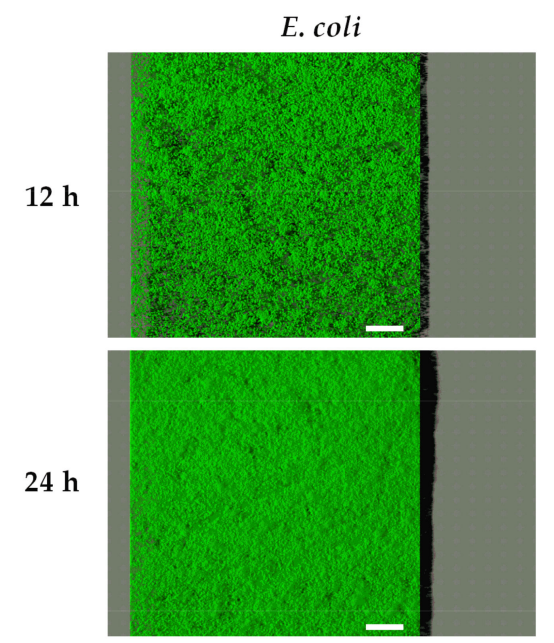

L. plantarum + E. coli

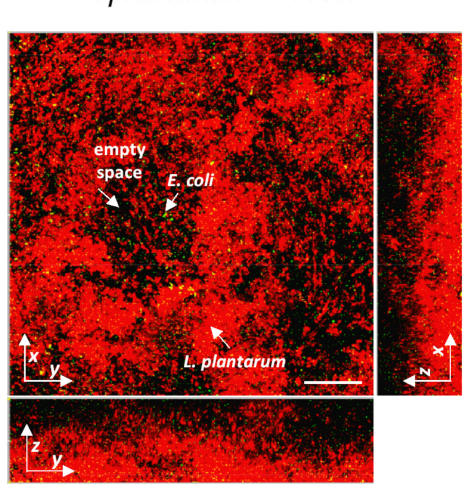

$24 \mathrm{~h}$

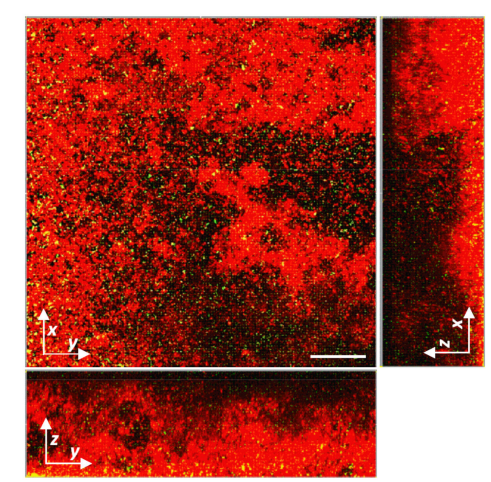

(b)
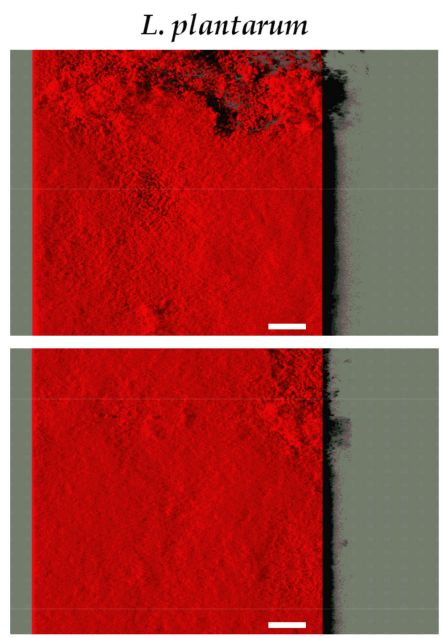

(a)
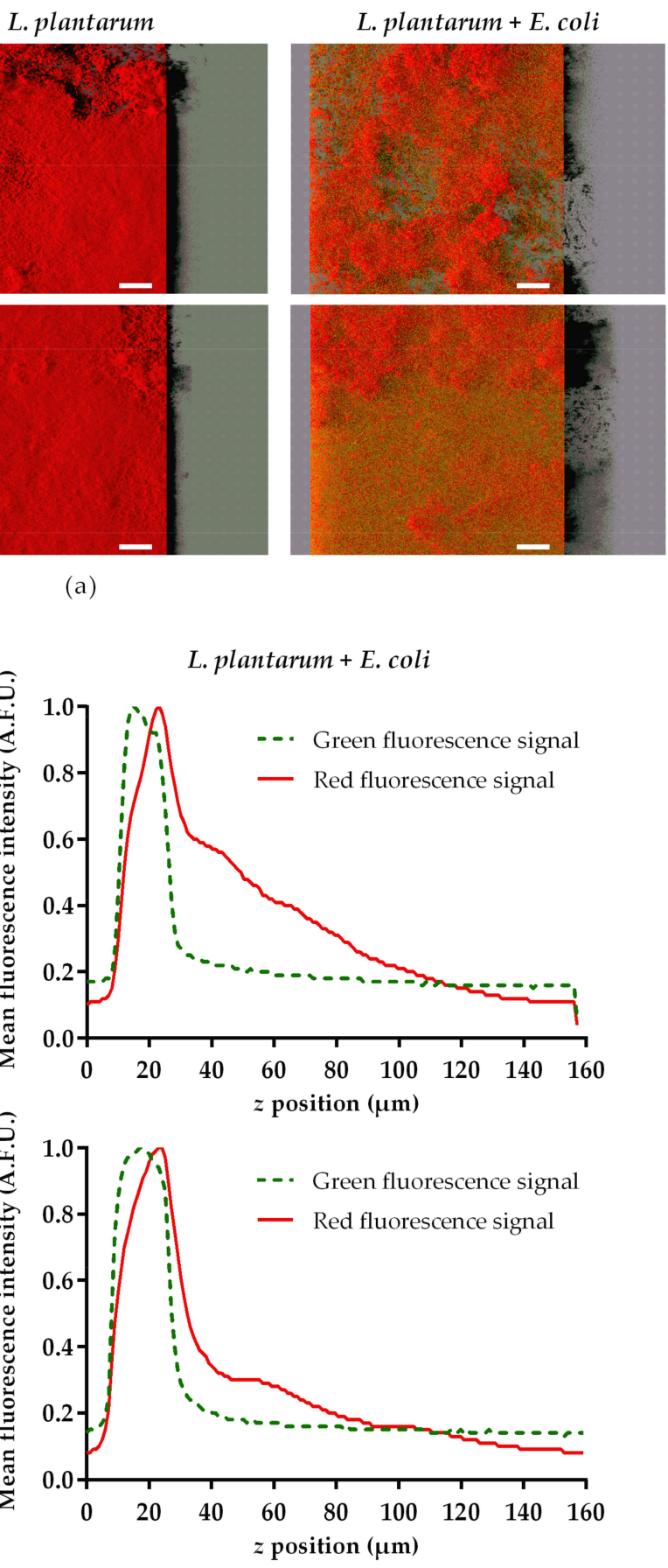

(c)

Figure 4. Spatial heterogeneity of 12- and 24-h biofilms from single- (E. coli CECT 434 GFP and L. plantarum) and dual-species (L. plantarum + E. coli CECT 434 GFP) cultures formed on silicone coupons: (a) aerial, three-dimensional (3D) view of the biofilms (shadow projection on the right); (b) section views of the CLSM images presented in (a) for the L. plantarum + E. coli CECT 434 GFP biofilms; and (c) distribution of normalized red and green fluorescence intensity values (arbitrary fluorescence units (A.F.U.)) along the vertical (z) biofilm position. The images in (a,b) were obtained from confocal $z$-stacks using IMARIS software. The white arrows in (b) indicate the presence of E. coli CECT 434 expressing GFP (labeled in green), L. plantarum (counterstained in red with Syto61), and empty spaces within the biofilm. Some yellow regions appear due to the red and green being superimposed. The white scale bars correspond to $50 \mu \mathrm{m}$ in (a) and $100 \mu \mathrm{m}$ in (b). 


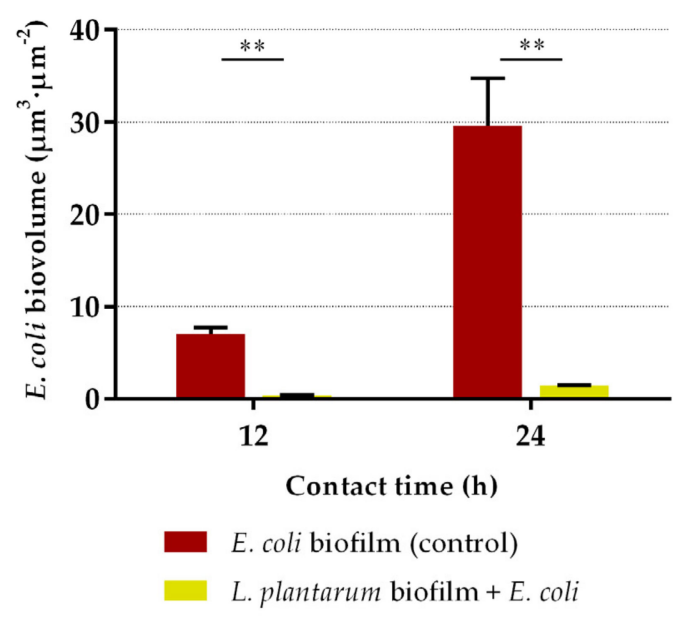

(a)

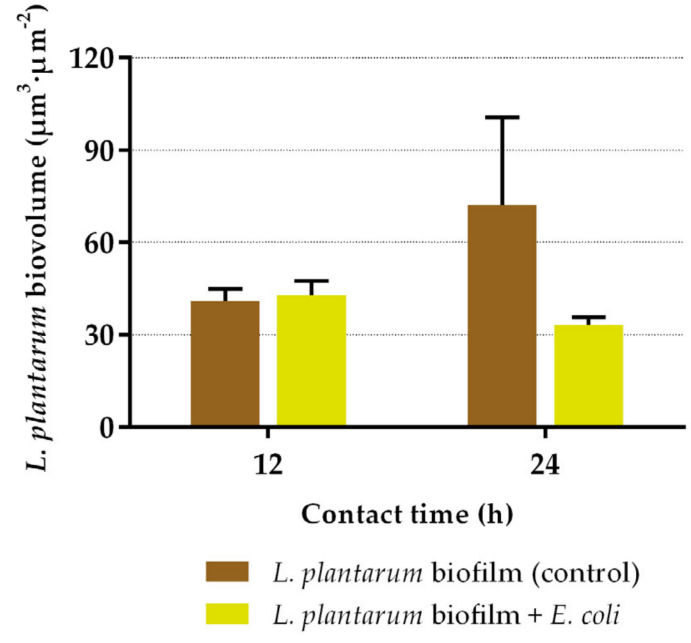

(b)

Figure 5. Biovolume of E. coli (a) and L. plantarum (b) after 12 and $24 \mathrm{~h}$ of contact between the pre-formed probiotic biofilm and the pathogen. This quantitative biofilm parameter was determined from confocal $z$-stacks using the plug-in COMSTAT2 associated with the ImageJ software. The data present the mean and standard deviation (SD) of at least five stacks of each sample. Statistically significant differences between the control and exposure were considered for $p$-values $<0.05$ (** indicates $p<0.01$ ).

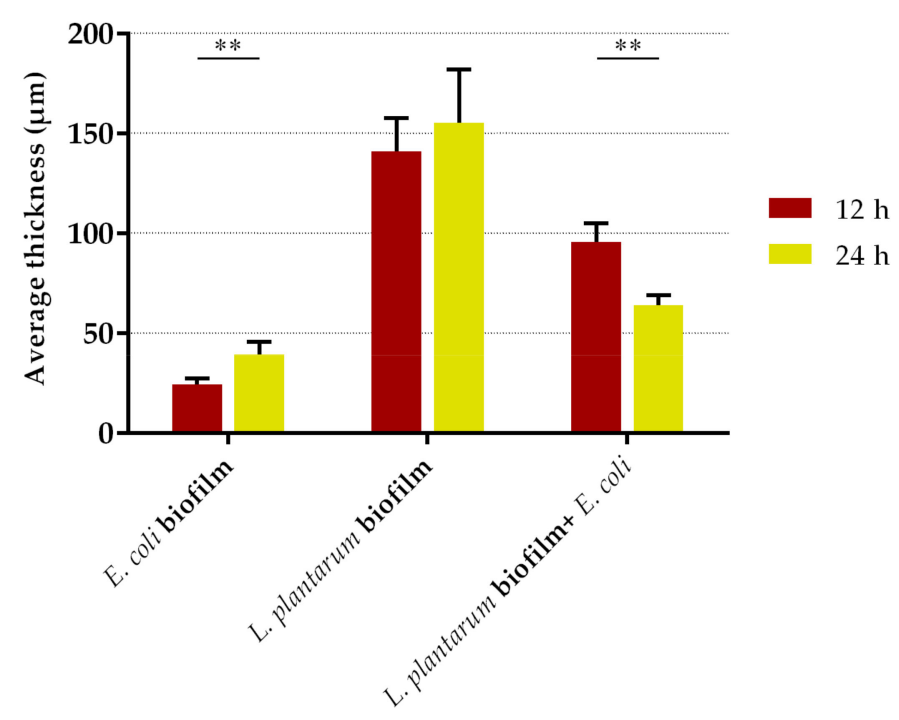

Figure 6. Thickness of single- (E. coli and L. plantarum) and dual-species (L. plantarum + E. coli) biofilms after 12 and $24 \mathrm{~h}$ of contact between the pre-formed probiotic biofilm and the pathogen. This quantitative biofilm parameter was determined from confocal z-stacks using the plug-in COMSTAT2 associated with the ImageJ software. The data present the mean and standard deviation (SD) of at least five stacks of each sample. Statistically significant differences between exposure times were considered for $p$-values $<0.05\left(^{* *}\right.$ indicates $\left.p<0.01\right)$.

\subsection{Thermodynamic Surface Properties}

The physicochemical interaction between E. coli CECT 434 GFP and silicone with and without $L$. plantarum biofilms were assessed through contact angle measurements and the calculation of the respective free energy $\left(\Delta G_{\text {sws }}\right)$ (Table 1). The water contact angle $\left(\theta_{w}\right)$ and the $\Delta G_{s w s}$ can be used as indicators of the hydrophobicity of a surface. The $\theta_{w}$ of $107.1 \pm 4.9^{\circ}$ and $\Delta G_{s w s}$ of $-62.4 \mathrm{~mJ} \cdot \mathrm{m}^{-2}$ of silicone indicated its hydrophobic character. Conversely, L. plantarum biofilms revealed a hydrophilic character, with a $\theta_{w}$ of $34.9 \pm 2.8^{\circ}$ and $\Delta G_{s w s}$ of $34.3 \mathrm{~mJ} \cdot \mathrm{m}^{-2}$. E. coli also demonstrated a hydrophilic character 
$\left(\theta_{w}=19.4 \pm 2.2^{\circ}\right.$ and $\left.\Delta G_{s w s}=131.2 \mathrm{~mJ} \cdot \mathrm{m}^{-2}\right)$, as is similar to previous studies with the same bacterial species [50].

Table 1. Contact angles with the three reference liquids (water, formamide, and $\alpha$-bromonaphthalene), surface and bacteria hydrophobicity, and energy of E. coli-surface interaction.

\begin{tabular}{|c|c|c|c|c|c|}
\hline \multirow[t]{2}{*}{ Sample } & \multicolumn{3}{|c|}{ Contact Angle $\left({ }^{\circ}\right)$} & \multirow{2}{*}{$\begin{array}{c}\begin{array}{c}\text { Hydrophobicity } \\
\left(\mathrm{mJ} \cdot \mathrm{m}^{-2}\right)\end{array} \\
\Delta G_{s w s}\end{array}$} & \multirow{2}{*}{$\begin{array}{c}\begin{array}{c}\text { E. coli-Surface } \\
\text { Interaction }\left(\mathrm{mJ} \cdot \mathrm{m}^{-2}\right)\end{array} \\
\Delta G_{\text {adhesion }}\end{array}$} \\
\hline & $\theta_{w}$ & $\theta_{F}$ & $\theta_{B}$ & & \\
\hline \multicolumn{6}{|l|}{ Surface } \\
\hline Bare silicone & $107.1 \pm 4.9$ & $100.7 \pm 2.4$ & $85.8 \pm 3.7$ & -62.4 & 36.1 \\
\hline L. plantarum biofilm & $34.9 \pm 2.8$ & $39.5 \pm 4.9$ & $23.1 \pm 2.6$ & 34.3 & 84.0 \\
\hline \multicolumn{6}{|l|}{ Bacteria } \\
\hline E. coli CECT 434 GFP & $19.4 \pm 2.2$ & $78.1 \pm 5.5$ & $62.2 \pm 4.9$ & 131.2 & N.A. \\
\hline
\end{tabular}

Abbreviations: $\theta_{w}$-water contact angle; $\theta_{F}$-formamide contact angle; $\theta_{B}$ - $\alpha$-bromonaphthalene contact angle; $\Delta G_{s w s}-$ free energy of interaction between two entities of a given material (s) (surface or bacteria) when immersed in water (w); $\Delta G_{\text {adhesion }}$-free energy of adhesion between $E$. coli and the surfaces when immersed in water; N.A.-not applicable. Values are means \pm SDs of three independent experiments.

Bacterial adhesion is favorable if the interactions lead to negative values of the free energy of adhesion $\left(\Delta G_{\text {adhesion }}\right)$ [51]. In this study, since the $\Delta G_{\text {adhesion }}$ between $E$. coli and the two surfaces (bare silicone and silicone coated with L. plantarum biofilm) had a positive value (Table 1), E. coli adhesion to silicone and L. plantarum biofilms was thermodynamically unfavorable. Furthermore, the $\Delta G_{\text {adhesion }}$ between E. coli and L. plantarum biofilms was higher than that between E. coli and bare silicone ( 84.0 versus $\left.36.1 \mathrm{~mJ} \cdot \mathrm{m}^{-2}\right)$, which means that $E$. coli is less prone to adhere to L. plantarum biofilms than to silicone, from a purely thermodynamic perspective.

\section{Discussion}

With the widespread use of urinary tract devices, the formation of microbial biofilms on their surfaces contributes to the increasing number of urinary infections. Recently, some studies have proposed the use of probiotics and their metabolites as a reliable option to inhibit pathogenic biofilm growth and/or to disperse pre-formed biofilms in human subjects [23]. Although probiotics may exert different effects against the activity of pathogenic bacteria (displacement, exclusion, and competition), avoiding the initial attachment of pathogens by coating the surfaces seems to be the best strategy to fight biofilm-based infections [22]. Thus, in this work, the potential of L. plantarum to prevent biofilm formation on UTDs was evaluated, following an exclusion strategy. This strategy consists of the formation of L. plantarum biofilms, followed by exposure to E. coli suspensions, in order to evaluate the ability of L. plantarum as a protective barrier to fence off and retard pathogen colonization. This strategy is relevant since various exometabolites of Lactobacillus strains may inhibit biofilm formation by interfering with the initial attachment of pathogens [52,53]. Compared to other coating strategies, the use of non-pathogenic cells to coat medical devices may be advantageous because the coating is alive. This allows for the self-renewal of the anti-pathogenic activity, whereas conventional coatings eventually become covered by biomass, which may reduce their effectiveness and lead to the loss of beneficial properties over time [40]. This approach also confers a sustainable antimicrobial pathway to preventing UTIs without inducing bacterial resistance [19].

The first goal of this study was to optimize the cultivation conditions for the formation of robust L. plantarum biofilms on silicone surfaces. L. plantarum demonstrated a high biofilm-forming ability in MRS broth, as expected, since MRS broth has been described as an appropriate growth medium for Lactobacillus strains [54]. L. plantarum culturability and biomass amount decreased over time, regardless of the growth medium and hydrodynamic conditions. This tendency may be associated with nutritional limitations inside the wells. Since the culture medium was not replaced during these first sets of experiments, most of 
the nutrients may have been depleted, leading to limitations in probiotic growth. Moreover, biofilms formed under the static mode presented significantly higher biomass amounts than those grown under high shaking conditions. However, we believe that these static biofilms consisted of poorly adhered cells as a result of sedimentation [55]. This characteristic was observed while unsticking the silicone coupons from the wells, where the static-formed biofilm often disintegrated. In order to overcome this issue, a second screening of the biofilm-forming capacity of L. plantarum was performed; a quasi-static condition was tested in order to obtain both the higher biomass content characteristic from static conditions and the cohesive character of biofilms formed under more intense shaking conditions. In addition, this second optimization round was performed only with MRS broth, and the effect of medium replacement on L. plantarum biofilm growth was assessed. Comparing the results of the two optimizations, it is clear that replacing the culture medium every day enhanced the number of culturable cells and biomass amount, overcoming possible nutritional limitations, and the use of quasi-static conditions led to the formation of more robust biofilms.

Other research groups evaluated the biofilm-forming capacity of L. plantarum and showed that different strains of L. plantarum were able to grow as a biofilm in MRS broth on abiotic surfaces, such as polystyrene and glass [29,56-59]. Klimko et al. [60] investigated the ability of LAB to form biofilms on a hydrophobic carrier, and L. plantarum was revealed to be the most prolific biofilm-forming bacterium. Several factors, such as the temperature, availability of nutrients, $\mathrm{pH}$, contact time with the surface, growth stage, and surface hydrophobicity, can affect biofilm development [61]. Fernández et al. [62] reported that the capacity of L. plantarum to form biofilms is highly affected by the composition of the culture medium, growth temperature, and time of incubation, as in our work. They found that L. plantarum biofilms typically contain proteins and/or proteinaceous material cementing the biofilm cells to the surface [62]. Several compounds are described to be directly related to the cell surface characteristics, such as lipoteichoic acid, outer membrane proteins and lipids, surface fibrils, various fimbriae, or polysaccharides [63,64]. Some authors suggested the existence of an S-layer, a mono-layer composed of identical proteins or glycoproteins, on the surface of specific Lactobacillus strains that are involved in the adhesion phenomenon [53]. Another key mechanism associated with biofilm formation is autoaggregation. The well-known ability of probiotic strains to auto-aggregate might promote adhesion to host cells or polymeric surfaces $[52,65,66]$. The ability of microorganisms to adhere to certain substrata depends on van der Waals attraction forces, gravitational forces, steric interactions, protein adhesion, and electrostatic interactions, but one of the more important factors is the hydrophobicity of the cells $[3,42,63]$. The hydrophobicity of the cell surface depends on the surface components of the bacterial cells, such as proteins and polysaccharides, and the adhesion phenomenon is influenced by the contact between the cell wall and the surface of attachment $[60,67]$. Previous studies reported the hydrophilic character of L. plantarum [56,67], this being in accordance with the hydrophilicity level determined in the present work. Millsap et al. [56] also demonstrated that urine components can affect the ability of lactobacilli to adhere to substrata [56]. However, this was not verified in the present work, as the culturability of L. plantarum biofilms was constant over time when in contact with AUM, showing that this culture medium does not influence lactobacilli viability and stability. Besides the cell surface properties, the characteristics of the surface material play an important role in bacterial adhesion, including the chemical composition, physicochemical properties (surface charge, hydrophobicity, topography, and roughness), and physicomechanical parameters (elastic modulus and hardness) [9]. Thus, the auto-aggregation capacity and efficient production of extracellular polymeric substances and other cell components may be responsible for maintaining the L. plantarum population adhered to the silicone coupons [68-71].

Regarding the antibiofilm activity of L. plantarum biofilms, they significantly inhibited E. coli proliferation by reducing its culturability in 24-h biofilms. Some possible applications for this short-term catheterization period are procedures where indwelling urinary catheters 
are used to assess urine output and prevent postoperative urinary retention. For example, 24-h catheterization may be used routinely after common gynecological procedures [72]. Randomized controlled trials suggested that a removal time of the urinary catheter at $\leq 6 \mathrm{~h}$ postoperatively seems to be more beneficial than immediate or $>6 \mathrm{~h}$ removal for patients undergoing gynecologic surgeries, decreasing both the ambulation time and hospital stay $[73,74]$. In fact, many clinical trials recommended the removal of urinary catheters within the first postoperative day (within a period ranging from 3 to $24 \mathrm{~h}$ ) for many surgical interventions that do not require long catheterization periods, such as pelvic rectal or colorectal resection surgery, gynecological procedures (gynecological laparotomy, cesarean section, colposuspension, vaginal plastic surgery, vaginal prolapse surgery, and vaginal, laparoscopic or abdominal hysterectomy) or urological surgeries (transurethral resection of the prostate) [74-83]. For operative patients who have an indication for an indwelling catheter, the removal of the catheter should be done as soon as possible postoperatively, preferably within $24 \mathrm{~h}$ [84]. To the best of our knowledge, this is the first study evaluating the short-term activity of pre-formed L. plantarum biofilms against E. coli colonization. Previously, Jalilsood et al. [59] evaluated the ability of an L. plantarum isolate to form strong biofilms, and its inhibitory effect against numerous spoilage and pathogenic bacteria, but for longer periods. The L. plantarum biofilms were formed over 7 days and, when exposed to bacteria, they significantly reduced the number of pathogens for up to 6 days.

The competitive features of probiotics depend on the ability to produce and release antimicrobial substances, compete for adhesion sites on the surface, and compete for limited resources with the pathogens $[57,85]$. Thus, the antagonizing effect of $L$. plantarum may be associated with antimicrobial and/or anti-adhesive properties.

The antimicrobial activity is correlated essentially with the production of antimicrobial substances, such as organic acids, hydrogen peroxide, exopolysaccharides, biosurfactants or bacteriocins, that can hinder adhesion to surfaces and generate unfavorable environmental conditions [21,22]. The production of organic acids, such as lactic and acetic acids, is one of the major antibacterial mechanisms of lactobacilli [86]. Organic acids have been shown to effectively inhibit microbial growth and kill Gram-negative bacteria like E. coli by lowering the $\mathrm{pH}$, causing cell membrane damage and the consequent leakage of intracellular material [52,87]. Lactobacilli may produce high concentrations of lactic acid and acetic acid, depending on their fermentative pathways and growth conditions. Teanpaisan et al. [88] reported that Lactobacillus strains increased their inhibitory activity when they were cultured in a medium with a higher glucose concentration, indicating that the availability of substrate for fermentation is one of the essential factors to exert inhibitory effects. MRS broth, the appropriate medium for Lactobacillus growth, contains a high glucose concentration, which enables both lactic and acetic acid production from glucose metabolism. However, in AUM, the concentration of glucose is residual, limiting the growth of L. plantarum and preventing medium acidification. Hence, other mechanisms of action besides organic acid production were probably implicated in the antimicrobial activity shown by L. plantarum.

The prevention of E. coli biofilm formation may be attributed to the bacteriocins produced by L. plantarum. Different studies demonstrated that the secretion of bacteriocins by lactobacilli can inhibit the growth of competitors [43,45,89-91]. Zalán et al. [92] demonstrated that $L$. plantarum seemed to be a good bacteriocin producer, and exhibited a remarkable inhibitory performance against several pathogens. Bacteriocins from L. plantarum have been shown to induce cell death through the inhibition of cell wall, nucleic acid and protein synthesis, or enzymatic activity [60]. Bacteriocins have several other proposed antimicrobial mechanisms, such as pore formation in the cell membrane, leading to cell leakage and consequent death [21,93].

Furthermore, the production of hydrogen peroxide by probiotics is very important because it has bactericidal effects on most pathogens [39]. L. plantarum was reported to have the ability to produce hydrogen peroxide [94], which can be toxic to organisms lacking hydrogen peroxide-scavenging enzymes [95]. The strong oxidizing effect of hydrogen peroxide on the bacterial cell, and the destruction of basic molecular structures 
of cell protein, is the basis of its bactericidal effect [96]. E. coli can protect itself from the oxidative stress of endogenous hydrogen peroxide through the action of peroxidases and catalases [97]. However, although E. coli tolerates low levels of intracellular hydrogen peroxide, if the concentration were allowed to rise much higher than $50 \mathrm{nM}$, vulnerable enzymes would quickly lose activity and the pathways to which they belong would cease to function [97]. Hydrogen peroxide can cause DNA damage and other uncharacterized damages at concentrations higher than $1 \mathrm{mM}$, and decrease the expression of virulence factors of E. coli [87,97-99]. Kang et al. [96] detected a concentration of $3.5 \mathrm{mM}$ of hydrogen peroxide in the culture medium of a Lactobacillus strain and indicated that the main inhibitory factor against $E$. coli was hydrogen peroxide. Thus, although the antimicrobial mechanisms suggested here require further research, the synergistic action of secreted bacteriocins or bacteriocin-like proteins and hydrogen peroxide might be related to the bactericidal activity of Lactobacillus strains against uropathogens.

Regarding the anti-adhesive properties of L. plantarum, it is most likely to be of an interfacial nature, presumably by the modification of the surface energy of E. coli cells, preventing them from clumping and forming an organized network [100]. Previous studies have demonstrated that biosurfactants produced by LAB were able to inhibit pathogens' adhesion to surfaces (including silicone-based materials) through both antimicrobial and anti-adhesive mechanisms [46,101-104], which can include the reduction of the hydrophobicity of surface substratum and consequently alter microbial adhesion, and the disruption of the cell membrane structure, leading to the release of cellular content and cell death $[21,28,46,105]$. In addition, the presence of exopolysaccharides may exert anti-adhesive effects by weakening cell surface modifications, interfering with cell-cell interactions and restricting the attachment of E. coli to the surface [106]. It was reported that exopolysaccharides produced by probiotics might have reduced QS signals involved in pathogenic biofilm formation [93]. Mahdhi et al. [107] proposed that exopolysaccharides produced by L. plantarum decreased cell surface hydrophobicity and indole production (a signal molecule involved in QS), hindering E. coli biofilm formation. In the present study, when E. coli was challenged with probiotic biofilms, it is believed that the inhibitory effect may also be associated with the integrity and cell culturability of L. plantarum biofilms, since the decreasing efficacy of $L$. plantarum biofilms at long periods $(24 \mathrm{~h})$ was accompanied by a decline in biovolume, biofilm thickness and number of L. plantarum culturable cells. This phenomenon may occur due to (1) the replacement of probiotic sessile cells by E. coli, (2) probiotic detachment from silicone surfaces, or (3) nutritional limitations resulting from the batch mode in which the assays were performed, which may lead to nutrient depletion (since L. plantarum has more restrictive growth requirements [31], and E. coli has a more efficient carbon and nitrogen metabolism under nutrient-limited conditions [108]). The differences in the free energy of adhesion also suggest that $E$. coli is less prone to adhere to L. plantarum biofilms than to silicone, which helps to explain the antibiofilm activity of $L$. plantarum and the preferential location of E. coli cells in the innermost layers of the biofilm.

The probiotic activity seems to be mainly related to bacterial interactions, the precolonization of adhesion sites by L. plantarum cells, and the production of substances that kill pathogens. The present work revealed that L. plantarum attachment on silicone-based surfaces may be a promising approach for preventing the formation of pathogenic biofilms.

\section{Materials and Methods}

\subsection{Preparation of Silicone Surfaces}

In order to mimic the typical surface material of urinary catheters, biofilm formation assays were performed on square silicone coupons with dimensions of $1 \times 1 \mathrm{~cm}$ (Neves \& Neves, Lda, Gondomar, Portugal) placed inside 12-well plates (VWR, Radnor, PA, USA). The coupons were firstly washed with 70\% $(v / v)$ ethanol (VWR, Radnor, PA, USA), dried at room temperature for $1 \mathrm{~h}$, and then sterilized through ultraviolet (UV) radiation for $30 \mathrm{~min}$ [109]. Double-sided adhesive tape was placed in each plate well, sterilized with UV radiation for $30 \mathrm{~min}$, and finally, the sterile coupons were glued in place. 


\subsection{Bacterial Strains and Culture Conditions}

The probiotic strain used in this study was Lactobacillus plantarum (kindly provided by Dr. Mette Burmølle, University of Copenhagen, Copenhagen, Denmark). L. plantarum was evaluated in terms of its biofilm-forming capacity and antibiofilm and anti-adhesive activities against uropathogens in exclusion assays. This strain was preserved at $-80{ }^{\circ} \mathrm{C}$ in MRS broth (Merck, Madrid, Spain) with 30\% (v/v) glycerol, streaked on MRS agar (Sharlab, Barcelona, Spain) plates, and incubated for $48 \mathrm{~h}$ at $37^{\circ} \mathrm{C}$. The inoculum was prepared by collecting bacterial colonies from the MRS agar plate into $250 \mathrm{~mL}$ of MRS broth and incubating overnight at $37^{\circ} \mathrm{C}$ in an orbital shaker at $120 \mathrm{rpm}$ (Agitorb 200; Aralab, Rio de Mouro, Portugal). Escherichia coli CECT 434 expressing GFP was used as a model strain of uropathogenic bacteria to perform the antibiofilm assays. For the construction of E. coli CECT $434 \mathrm{GFP}$, the previously described pCM11 plasmid carrying the gene-encoding superfolder GFP (sGFP) and conferring ampicillin resistance was introduced in the CECT 434 strain by the heat shock method [110]. This bacterial strain was preserved at $-80{ }^{\circ} \mathrm{C}$ in Luria-Bertani (LB) broth (Thermo Fisher Scientific, Waltham, MA, USA) containing 30\% $(v / v)$ glycerol, streaked on LB agar plates supplemented with ampicillin at $0.1 \mathrm{~g} \cdot \mathrm{L}^{-1}$ to maintain pCM11 in E. coli CECT 434, and incubated for $24 \mathrm{~h}$ at $37^{\circ} \mathrm{C}$. Single colonies were collected from LB agar plates, inoculated in $250 \mathrm{~mL}$ of AUM supplemented with ampicillin [111], and incubated overnight at $37^{\circ} \mathrm{C}$ and $120 \mathrm{rpm}$ to prepare a starting culture. AUM was used for $E$. coli growth since it provides nutritional conditions similar to those found in human urine.

\subsection{Biofilm-Forming Capacity of L. plantarum}

An initial screening of the biofilm-forming capacity of L. plantarum was performed, testing different culture media, hydrodynamic conditions, and periods of biofilm formation, in order to determine the optimal conditions to form more robust biofilms. These were further used in antibiofilm assays (Section 4.4). L. plantarum, grown overnight in MRS broth, was harvested by centrifugation at $3202 \times \mathrm{g}$ for $10 \mathrm{~min}$ at $25^{\circ} \mathrm{C}$ (Eppendorf Centrifuge 5810R; Eppendorf AG, Hamburg, Germany), and the final cell concentration was adjusted to an optical density at $610 \mathrm{~nm}\left(\mathrm{OD}_{610} \mathrm{~nm}\right)$ of 0.7 in fresh AUM and MRS broth, equivalent to approximately $10^{8}$ colony-forming units per $\mathrm{mL}\left(\mathrm{CFU} \cdot \mathrm{mL}^{-1}\right)$, as confirmed by $\mathrm{CFU}$ counts. Biofilm formation assays were performed on silicone coupons placed inside sterile 12-well plates, where each well was loaded with $3 \mathrm{~mL}$ of $L$. plantarum suspension. The plates were incubated for 24,48 and $72 \mathrm{~h}$ at $37^{\circ} \mathrm{C}$ under static and high shaking (100 rpm) conditions. These conditions were tested because the colonization of urinary catheters by uropathogenic strains can occur in both hydrodynamic environments: static conditions mimic the extraluminal surfaces in the urethra [9], while high shaking conditions generate shear stresses similar to those found inside the urinary catheter due to the flow of urine [9].

A second screening experiment was performed, where L. plantarum biofilms were formed in MRS broth for 24,48 and $72 \mathrm{~h}$ at $37{ }^{\circ} \mathrm{C}$ under quasi-static ( $40 \mathrm{rpm}$ ) and high shaking conditions, with replacement of the medium every day by the aspiration of supernatant from wells and the addition of fresh medium. The quasi-static conditions mimic the low shear stresses found on the outer side of urinary catheters and stents housed inside the bladder [9]. Negative controls with $3 \mathrm{~mL}$ of sterile AUM and MRS broth were prepared to evaluate the surface sterility throughout the experiments.

After incubation, the suspensions were removed from the wells, the biofilms were gently rinsed with sodium chloride solution $\left(\mathrm{NaCl} 8.5 \mathrm{~g} \cdot \mathrm{L}^{-1}\right)$ to remove the non-adherent cells, and the biofilm amount and culturability were assessed by crystal violet (CV) staining (Section 4.6) and CFU counts (Section 4.5), respectively. All experiments included at least three independent biological replicates, and each replicate included two technical replicates. 


\subsection{Antibiofilm Assays}

The antibiofilm assays followed an exclusion strategy [22] that consisted of the exposure of L. plantarum biofilms, pre-formed in the optimal cultivation conditions found in Section 2.1 (for $48 \mathrm{~h}$ in MRS broth under quasi-static conditions with medium replacement every $24 \mathrm{~h}$ ), to E. coli. Briefly, L. plantarum biofilms were formed on silicone coupons placed inside 12-well plates, as described above. Afterward, cell suspensions were removed, and each well was inoculated with $3 \mathrm{~mL}$ of $E$. coli suspension. For this test, after overnight incubation, E. coli cells were harvested by centrifugation $\left(3202 \times g, 10 \mathrm{~min}, 25^{\circ} \mathrm{C}\right)$, the cell concentration was adjusted to an $\mathrm{OD}_{610 \mathrm{~nm}}$ of 0.15 in $\mathrm{AUM}$, equivalent to a concentration of $10^{8} \mathrm{CFU} \cdot \mathrm{mL}^{-1}$, and a 100 -fold dilution was performed in order to obtain a final concentration of $10^{6} \mathrm{CFU} \cdot \mathrm{mL}^{-1}$, a representative dose of the minimal bacterial numbers found in the urogenital area [9]. Two negative controls were prepared: the first by adding the E. coli suspension to bare silicone, and the second by adding sterile AUM to L. plantarum biofilms. Plates were incubated at $37^{\circ} \mathrm{C}$ for periods of contact of $3,6,12$ and $24 \mathrm{~h}$ under quasi-static conditions $(40 \mathrm{rpm})$ and, at the end of each experimental period, biofilms were monitored as described below. The ability of L. plantarum biofilms to maintain their integrity in AUM and inhibit E. coli biofilm formation was also assessed by plate count enumeration and confocal laser scanning microscopy (CLSM). All experiments included at least three independent biological replicates, and each replicate included two technical replicates.

\subsection{Colony-Forming Units (CFU) Enumeration}

The number of biofilm culturable cells per $\mathrm{cm}^{2}$ of silicone was determined by CFU counts. After washing off the non-adhered cells, the coupons were transferred to $15 \mathrm{~mL}$ Falcon tubes with $2 \mathrm{~mL}$ of sodium chloride solution $\left(\mathrm{NaCl} 8.5 \mathrm{~g} \cdot \mathrm{L}^{-1}\right)$. Biofilm cells were detached from the coupons by vortexing (ZX4; VELP Scientifica Srl, Usmate, Italy) for $2 \mathrm{~min}$ at full power, and the obtained biofilm cell suspensions were serially diluted in sodium chloride solution, plated on LB agar supplemented with ampicillin (for E. coli) and MRS agar (for L. plantarum), and incubated at $37^{\circ} \mathrm{C}$ for 24 and $48 \mathrm{~h}$, respectively, for CFU enumeration. The percentages of CFU reduction of E. coli and L. plantarum were estimated according to Equation (1):

$$
\text { Reduction }(\%)=\frac{C F U_{\text {control }}-C F U_{\text {biofilm }}}{C F U_{\text {control }}} \times 100
$$

where $C F U_{\text {control }}$ corresponds to the culturable cells of $E$. coli on bare silicone or of L. plantarum biofilms exposed to sterile AUM, and $C F U_{\text {biofilm }}$ corresponds to culturable cells of E. coli or L. plantarum in biofilms developed on silicone coated with L. plantarum.

\subsection{Crystal Violet (CV) Staining}

The total biomass of L. plantarum biofilms was quantified using the CV staining method, which is based on the ability of the CV dye to color some components present in the biofilm matrix and be retained by the peptidoglycan wall of both living and dead bacterial cells [112]. The protocol was adapted from previous works [113,114]. Briefly, after washing the biofilms, the silicone coupons were transferred to 24-well plates (Thermo Fisher Scientific, Waltham, MA, USA) to quantify only the amount of biofilm formed on the coupon. Biofilms were fixed with $1 \mathrm{~mL}$ of $100 \%$ ethanol (VWR, Radnor, PA, USA), which was removed after $15 \mathrm{~min}$ of contact. Then, the wells were air-dried, and $1 \mathrm{~mL}$ of $1 \%(v / v)$ CV (Merck, Taufkirchen, Germany) aqueous solution was added to each well and incubated for $5 \mathrm{~min}$. The dye bound to the biofilm was solubilized by adding $1 \mathrm{~mL}$ of 33\% $(v / v)$ acetic acid (VWR, Radnor, PA, USA) aqueous solution. Finally, $200 \mu \mathrm{L}$ from each well was transferred to a 96-well polystyrene plate (VWR, Radnor, PA, USA), and the biofilm biomass was determined through its measured absorbance at $570 \mathrm{~nm}$ in a microtiter plate reader (SpectroStar Nano; BMG LABTECH, Ortenberg, Germany). When absorbance values exceeded 1 , samples were diluted in $33 \%(v / v)$ acetic acid, and the 
resulting measurements were corrected for the dilution factor. Absorbance measurements were corrected by subtracting the average of the blank control (wells containing surfaces not exposed to bacteria). The biofilm amount was plotted as Abs $570 \mathrm{~nm}$ values.

\subsection{Confocal Laser Scanning Microscopy (CLSM) Analysis}

To assess the spatial organization of biofilms and extract their quantitative structural parameters, the two control groups (E. coli and L. plantarum single-species biofilms formed on bare silicone) and the treatment group ( $E$. coli biofilms formed on silicone pre-coated with L. plantarum biofilms), corresponding to the experimental periods of 12 and $24 \mathrm{~h}$, were visualized by CLSM. The L. plantarum on the biofilms was counterstained in red with $5 \mu \mathrm{M}$ Syto61 (Invitrogen, Illkirch-Graffenstaden, France), a cell-permeant nucleic acid marker, for $10 \mathrm{~min}$. Each stained coupon was inverted, mounted on a coverslip, and scanned using a $40 \times$ water objective (Leica HCX PL APO CS; Leica Microsystems GmbH, Wetzlar, Germany) in an inverted microscope Leica DMI6000-CS with a 488-nm argon laser and 633-nm helium-neon laser. The emitted fluorescence was recorded within the range of 500-580 nm to collect the GFP emission fluorescence and 640-730 nm to collect the Syto61 fluorescence. A minimum of five stacks of horizontal plane images $(512 \times 512$ pixels, corresponding to $387.5 \mu \mathrm{m} \times 387.5 \mu \mathrm{m}$ ) with a z-step of $1 \mu \mathrm{m}$ was acquired for each biofilm sample.

Three- and two-dimensional projections of the biofilm structures were reconstructed from the CLSM acquisitions, using the "Easy 3D" and "Section" functions of IMARIS 9.1 software (Bitplane AG, Zurich, Switzerland), respectively. The plug-in COMSTAT2 associated with the ImageJ software was used to determine the biovolume $\left(\mu \mathrm{m}^{3} \cdot \mu \mathrm{m}^{-2}\right)$, biofilm thickness $(\mu \mathrm{m})$, and surface coverage (\%) [115]. The Stack Profile tool provided by the LAS AF Lite software (Leica Microsystems $\mathrm{GmbH}$ ) was also used to trace the intensity values of both fluorescence signals concerning the $z$-position.

\subsection{Contact Angle Measurements, Hydrophobicity, and Free Energy of Adhesion between Bacteria and Substrates}

The free energy of adhesion $\left(\Delta G_{\text {adhesion }}\right)$ between $E$. coli and all tested substrates (bare silicone and silicone coated with L. plantarum biofilm) was assessed according to the procedure described by Alves et al. [49]. Lawns of E. coli were prepared to ascertain the bacterial surface hydrophobicity. Briefly, E. coli substrate was prepared by collecting bacterial cells from an overnight culture (grown under the conditions described in Section 4.4) on a cellulose membrane (pore diameter of $0.45 \mu \mathrm{m}$; Advantec, Japan) to a density of $1 \times 10^{8} \mathrm{cell} \cdot \mathrm{mm}^{-2}$. Strips (with a width of $1 \mathrm{~cm}$ ) were cut from the membranes and fixed onto a glass slide for contact angle determination. L. plantarum biofilms were formed as described in Section 4.4 .

The contact angles of the bacteria and the substrates were determined by the sessile drop method, using a contact angle meter (OCA 15 Plus; DataPhysics, Filderstadt; Germany). The surface tension components of the bacteria and the adhesion surfaces were obtained by measuring the contact angles with three pure liquids $(I)$ : water, formamide and $\alpha$-bromonaphthalene (Sigma-Aldrich Co., Lisboa, Portugal). The surface tension components of the reference liquids were obtained from the literature [116]. Contact angle measurements were performed at room temperature $\left(25 \pm 2{ }^{\circ} \mathrm{C}\right)$ in three independent experiments, and at least 20 determinations for each liquid, material, and microorganism were made. Afterward, the hydrophobicity of the bacteria and the surfaces were evaluated using the method of van Oss et al. [117-119]. In this approach, the degree of hydrophobicity of a given material (s) (surface or bacteria) is expressed as the free energy of interaction between two entities of that material when immersed in water $(w)-\Delta G_{s w s}$. If the interaction between the two entities is stronger than the interaction of each entity with water $\left(\Delta G_{s w s}<0 \mathrm{~mJ} \cdot \mathrm{m}^{-2}\right)$, the material is considered hydrophobic. Conversely, if 
$\Delta G_{s w s}>0 \mathrm{~mJ} \cdot \mathrm{m}^{-2}$, the material is hydrophilic. $\Delta G_{s w s}$ was calculated from the surface tension components of the interacting entities, according to Equation (2):

$$
\Delta G_{s w s}=-2\left(\sqrt{\gamma_{s}^{L W}}-\sqrt{\gamma_{w}^{L W}}\right)^{2}+4\left(\sqrt{\gamma_{s}^{+} \gamma_{w}^{-}}+\sqrt{\gamma_{s}^{-} \gamma_{w}^{+}}-\sqrt{\gamma_{s}^{+} \gamma_{s}^{-}}-\sqrt{\gamma_{w}^{+} \gamma_{w}^{-}}\right)
$$

where $\gamma^{L W}$, defined as $\gamma^{L W}=11.1 \times\left(1+\cos \theta_{B}\right)^{2}$ where $\theta_{B}$ is the contact angle determined using $\alpha$-bromonaphthalene, accounts for the Lifshitz-van der Waals component of the surface free energy, and $\gamma^{+}$and $\gamma^{-}$are the electron acceptor and electron donor parameters, respectively, of the Lewis acid-base component, $\gamma^{A B}$, with $\gamma^{A B}=2 \sqrt{\gamma^{+} \gamma^{-}}$.

The surface tension components were estimated by the simultaneous resolution of three equations of the type of Equation (3):

$$
\left(1+\cos \theta_{I}\right) \gamma_{s}^{T O T}=2\left(\sqrt{\gamma_{s}^{L W} \gamma_{I}^{L W}}+\sqrt{\gamma_{s}^{+} \gamma_{I}^{-}}+\sqrt{\gamma_{s}^{-} \gamma_{I}^{+}}\right)
$$

where $\theta_{I}$ is the contact angle for each liquid, and $\gamma^{T O T}=\gamma^{L W}+\gamma^{A B}$.

When studying the interaction (free energy of adhesion) between $E$. coli $(b)$ and the surfaces of adhesion (s) when immersed in water $(w)$, the total interaction energy, $\Delta G_{a d h e s i o n}$, can be determined using Equation (4):

$$
\Delta G_{\text {adhesion }}=\gamma_{s b}^{L W}-\gamma_{s w}^{L W}-\gamma_{b w}^{L W}+2\left[\sqrt{\gamma_{w}^{+}}\left(\sqrt{\gamma_{s}^{-}}+\sqrt{\gamma_{b}^{-}}-\sqrt{\gamma_{w}^{-}}\right)+\sqrt{\gamma_{w}^{-}}\left(\sqrt{\gamma_{s}^{+}}+\sqrt{\gamma_{b}^{+}}-\sqrt{\gamma_{w}^{+}}\right)-\sqrt{\gamma_{s}^{+} \gamma_{b}^{-}}-\sqrt{\gamma_{s}^{-}} \gamma_{b}^{+}\right]
$$

Thermodynamically, if $\Delta G_{\text {adhesion }}<0 \mathrm{~mJ} \cdot \mathrm{m}^{-2}$, the adhesion of the bacteria to the substratum is favorable, whereas adhesion is not favorable if $\Delta G_{\text {adhesion }}>0 \mathrm{~mJ} \cdot \mathrm{m}^{-2}$.

\subsection{Statistical Analysis}

Statistical analysis was performed using the IBM SPSS Statistics version 26 for Windows (IBM SPSS, Inc., Chicago, IL, USA). Descriptive statistics were used to calculate the mean and SD (from at least three experiments with duplicates) for the number of culturable cells, biofilm mass, and quantitative CLSM analysis (biovolume and biofilm thickness). The homogeneity of variances and the normality of data were verified for all response variables tested, using the Kolmogorov-Smirnov and Shapiro-Wilk tests. Since the number of culturable cells, biofilm mass and CLSM parameters were not normally distributed, a nonparametric analysis using the Kruskal-Wallis test was performed to assess whether there were statistically significant differences among groups, and the Mann-Whitney test was conducted to determine the differences between those groups. Statistically significant differences were considered for $p$-values < 0.05 , corresponding to a confidence level of $95 \%$.

\section{Conclusions}

Overall, L. plantarum showed promising results against pathogenic biofilms developed on a polymeric surface. L. plantarum was able to form stable biofilms on silicone surfaces. Its biofilm-forming capacity was affected by the composition and frequency of culture medium replacement, hydrodynamic conditions, and the time of incubation. L. plantarum demonstrated good short-term activity in inhibiting E. coli adhesion to silicone. We suggested that the antibiofilm activity observed by L. plantarum biofilms was mainly attributable to the anti-adhesive properties associated with the competitive exclusion mechanism that prevents the adhesion of E. coli on the surfaces. The killing of E. coli may also have occurred via the production of antimicrobial compounds, such as bacteriocins, hydrogen peroxide, exopolysaccharides, and biosurfactants. Thus, coating the surface with probiotics may be a promising strategy to prevent the initial attachment of pathogens in silicone-based medical settings. 
Author Contributions: Conceptualization, F.J.M.M. and L.C.G.; methodology, F.M.C. and L.C.G.; software, F.M.C., R.T.-S. and L.C.G.; investigation, F.M.C. and L.C.G.; resources, F.J.M.M. and L.C.G.; data curation, F.M.C., R.T.-S. and L.C.G.; writing-original draft preparation, F.M.C.; writing-review and editing, F.M.C., R.T.-S., F.J.M.M. and L.C.G.; supervision, F.J.M.M. and L.C.G. All authors have read and agreed to the published version of the manuscript.

Funding: This research was funded by: national funds of the Portuguese Foundation for Science and Technology (FCT) and Direção Geral do Ensino Superior (DGES) budgets in the scope of the special support "Verão com Ciência"; Base Funding-UIDB/00511/2020 of the Laboratory for Process Engineering, Environment, Biotechnology and Energy_LEPABE—funded by national funds through the FCT/MCTES (PIDDAC); and project PTDC/CTMCOM/4844/2020. L.C.G. thanks the FCT for financial support of her work contract through the Scientific Employment Stimulus-Individual Call (CEECIND/01700/2017).

Institutional Review Board Statement: Not applicable.

Informed Consent Statement: Not applicable.

Data Availability Statement: The data presented in this study are available on request from the corresponding author. The data are not publicly available yet as some data sets are being used for additional publications.

Acknowledgments: Mette Burmølle from the Department of Biology, University of Copenhagen, is acknowledged for providing the L. plantarum strain.

Conflicts of Interest: The authors declare no conflict of interest.

\section{References}

1. Corte, L.; Pierantoni, D.C.; Tascini, C.; Roscini, L.; Cardinali, G. Biofilm specific activity: A measure to quantify microbial biofilm. Microorganisms 2019, 7, 73. [CrossRef]

2. Rabin, N.; Zheng, Y.; Opoku-Temeng, C.; Du, Y.; Bonsu, E.; Sintim, H.O. Biofilm formation mechanisms and targets for developing antibiofilm agents. Future Med. Chem. 2015, 7, 493-512. [CrossRef] [PubMed]

3. Khatoon, Z.; McTiernan, C.D.; Suuronen, E.J.; Mah, T.F.; Alarcon, E.I. Bacterial biofilm formation on implantable devices and approaches to its treatment and prevention. Heliyon 2018, 4, e01067. [CrossRef] [PubMed]

4. Azevedo, A.S.; Almeida, C.; Melo, L.F.; Azevedo, N.F. Impact of polymicrobial biofilms in catheter-associated urinary tract infections. Crit. Rev. Microbiol. 2017, 43, 423-439. [CrossRef] [PubMed]

5. Song, H.; Zhang, J.; Qu, J.; Liu, J.; Yin, P.; Zhang, G.; Shang, D. Lactobacillus rhamnosus GG microcapsules inhibit Escherichia coli biofilm formation in coculture. Biotechnol. Lett. 2019, 41, 1007-1014. [CrossRef]

6. Medina, M.; Castillo-Pino, E. An introduction to the epidemiology and burden of urinary tract infections. Ther. Adv. Urol. 2019, 11, 1756287219832172. [CrossRef] [PubMed]

7. OECD/EU Health at a Glance: Europe 2018 State of Health in the EU Cycle. Available online: https://doi.org/10.1787/health_ glance_eur-2018-en (accessed on 3 August 2021).

8. Maharjan, G.; Khadka, P.; Siddhi Shilpakar, G.; Chapagain, G.; Dhungana, G.R. Catheter-Associated Urinary Tract Infection and Obstinate Biofilm Producers. Can. J. Infect. Dis. Med. Microbiol. 2018, 2018, 7624857. [CrossRef] [PubMed]

9. Ramstedt, M.; Ribeiro, I.A.C.; Bujdakova, H.; Mergulhão, F.J.M.; Jordao, L.; Thomsen, P.; Alm, M.; Burmølle, M.; Vladkova, T.; Can, F.; et al. Evaluating efficacy of antimicrobial and antifouling materials for urinary tract medical devices: Challenges and recommendations. Macromol. Biosci. 2019, 19, e1800384. [CrossRef]

10. Feneley, R.C.L.; Hopley, I.B.; Wells, P.N.T. Urinary catheters: History, current status, adverse events and research agenda. J. Med. Eng. Technol. 2015, 39, 459-470. [CrossRef]

11. Singha, P.; Locklin, J.; Handa, H. A review of the recent advances in antimicrobial coatings for urinary catheters. Acta Biomater. 2017, 50, 20-40. [CrossRef] [PubMed]

12. Centers for Disease Control and Prevention. Catheter-associated Urinary Tract Infections (CAUTI). Available online: https: / / www.cdc.gov/hai/ca_uti/uti.html (accessed on 4 August 2021).

13. Lawrence, E.L.; Turner, I.G. Materials for urinary catheters: A review of their history and development in the UK. Med. Eng. Phys. 2005, 27, 443-453. [CrossRef]

14. Donlan, R.M. Biofilms and device-associated infections. Emerg. Infect. Dis. 2001, 7, 277-281. [CrossRef] [PubMed]

15. Seif Eldein, S.S.; El-Temawy, A.-E.-K.A.; Ahmed, E.H. Biofilm Formation by E. coli Causing Catheter Associated Urinary Tract Infection (CAUTI) in Assiut University Hospital. Egypt. J. Med. Microbiol. 2013, 22, 101-110. [CrossRef]

16. Niveditha, S.; Pramodhini, S.; Umadevi, S.; Kumar, S.; Stephen, S. The isolation and the biofilm formation of uropathogens in the patients with catheter associated urinary tract infections (UTIs). J. Clin. Diagn. Res. 2012, 6, 1478-1482. [CrossRef] [PubMed]

17. Anderson, G.G.; Palermo, J.J.; Schilling, J.D.; Roth, R.; Heuser, J.; Hultgren, S.J. Intracellular bacterial biofilm-like pods in urinary tract infections. Science 2003, 301, 105-107. [CrossRef] [PubMed] 
18. Chen, M.; Yu, Q.; Sun, H. Novel strategies for the prevention and treatment of biofilm related infections. Int. J. Mol. Sci. 2013, 14, 18488-18501. [CrossRef] [PubMed]

19. Zhu, Z.; Wang, Z.; Li, S.; Yuan, X. Antimicrobial strategies for urinary catheters. J. Biomed. Mater. Res. Part A 2019, 107, 445-467. [CrossRef] [PubMed]

20. Walencka, E.; Różalska, S.; Sadowska, B.; Rózalska, B. The influence of Lactobacillus acidophilus-derived surfactants on staphylococcal adhesion and biofilm formation. Folia Microbiol. 2008, 53, 61-66. [CrossRef]

21. Barzegari, A.; Kheyrolahzadeh, K.; Mahdi, S.; Khatibi, H.; Sharifi, S.; Memar, M.Y.; Vahed, S.Z. The battle of probiotics and their derivatives against biofilms. Infect. Drug Resist. 2020, 13, 659-672. [CrossRef] [PubMed]

22. Carvalho, F.M.; Teixeira-Santos, R.; Mergulhão, F.J.M.; Gomes, L.C. The use of probiotics to fight biofilms in medical devices: A systematic review and meta-analysis. Microorganisms 2021, 9, 27. [CrossRef]

23. Carvalho, F.M.; Teixeira-Santos, R.; Mergulhão, F.J.M.; Gomes, L.C. Targeting biofilms in medical devices using probiotic cells: A systematic review. AIMS Mater. Sci. 2021, 8, 501-523. [CrossRef]

24. FAO. Probiotics in Food: Health and Nutritional Properties and Guidelines for Evaluation. Food \& Agriculture Org: Rome, Italy, 2006; Available online: http:/ /www.fao.org/3/a0512e/a0512e.pdf (accessed on 9 August 2021).

25. Reis, J.A.; Paula, A.T.; Casarotti, S.N.; Penna, A.L.B. Lactic Acid Bacteria Antimicrobial Compounds: Characteristics and Applications. Food Eng. Rev. 2012, 4, 124-140. [CrossRef]

26. Fioramonti, J.; Theodorou, V.; Bueno, L. Probiotics: What are they? What are their effects on gut physiology? Best Pract. Res. Clin. Gastroenterol. 2003, 17, 711-724. [CrossRef]

27. Gogineni, V.K.; Morrow, L.E. Probiotics: Mechanisms of action and clinical applications. J. Probiotics Health 2013, 1, 101. [CrossRef]

28. Gomaa, E.Z. Antimicrobial and anti-adhesive properties of biosurfactant produced by lactobacilli isolates, biofilm formation and aggregation ability. J. Gen. Appl. Microbiol. 2013, 59, 425-436. [CrossRef]

29. Aoudia, N.; Rieu, A.; Briandet, R.; Deschamps, J.; Chluba, J.; Jego, G.; Garrido, C.; Guzzo, J. Biofilms of Lactobacillus plantarum and Lactobacillus fermentum: Effect on stress responses, antagonistic effects on pathogen growth and immunomodulatory properties. Food Microbiol. 2016, 53, 51-59. [CrossRef] [PubMed]

30. Khalighi, A.; Behdani, R.; Kouhestani, S. Probiotics: A comprehensive review of their classification, mode of action and role in human nutrition. In Probiotics and Prebiotics in Human Nutrition and Health; InTech: London, UK, 2016.

31. Prabhurajeshwar, C.; Chandrakanth, R.K. Probiotic potential of lactobacilli with antagonistic activity against pathogenic strains: An in vitro validation for the production of inhibitory substances. Biomed. J. 2017, 40, 270-283. [CrossRef]

32. Muñoz, M.; Mosquera, A.; Alméciga-Díaz, C.J.; Melendez, A.P.; Sánchez, O.F. Fructooligosaccharides metabolism and effect on bacteriocin production in Lactobacillus strains isolated from ensiled corn and molasses. Anaerobe 2012, 18, 321-330. [CrossRef] [PubMed]

33. Kechagia, M.; Basoulis, D.; Konstantopoulou, S.; Dimitriadi, D.; Gyftopoulou, K.; Skarmoutsou, N.; Fakiri, E.M. Health benefits of probiotics: A review. ISRN Nutr. 2013, 2013, 481651. [CrossRef]

34. Holzapfel, W.H.; Haberer, P.; Geisen, R.; Björkroth, J.; Schillinger, U. Taxonomy and important features of probiotic microorganisms in food and nutrition. Am. J. Clin. Nutr. 2001, 73, 365-373. [CrossRef]

35. De Melo Pereira, G.V.; de Oliveira Coelho, B.; Magalhães Júnior, A.I.; Thomaz-Soccol, V.; Soccol, C.R. How to select a probiotic? A review and update of methods and criteria. Biotechnol. Adv. 2018, 36, 2060-2076. [CrossRef]

36. Ng, S.C.; Hart, A.L.; Kamm, M.A.; Stagg, A.J.; Knight, S.C. Mechanisms of action of probiotics: Recent advances. Inflamm. Bowel Dis. 2009, 15, 300-310. [CrossRef]

37. Bermudez-Brito, M.; Plaza-Díaz, J.; Muñoz-Quezada, S.; Gómez-Llorente, C.; Gil, A. Probiotic mechanisms of action. Ann. Nutr. Metab. 2012, 61, 160-174. [CrossRef]

38. Salas-Jara, M.; Ilabaca, A.; Vega, M.; García, A. Biofilm Forming Lactobacillus: New Challenges for the Development of Probiotics. Microorganisms 2016, 4, 35. [CrossRef] [PubMed]

39. Nemcová, R. Criteria for selection of lactobacilli for probiotic use. Vet. Med. 1997, 42, 19-27.

40. Chen, Q.; Zhu, Z.; Wang, J.; Lopez, A.I.; Li, S.; Kumar, A.; Yu, F.; Chen, H.; Cai, C.; Zhang, L. Probiotic E. coli Nissle 1917 biofilms on silicone substrates for bacterial interference against pathogen colonization. Acta Biomater. 2017, 50, 353-360. [CrossRef]

41. Cadieux, P.; Watterson, J.D.; Denstedt, J.; Harbottle, R.R.; Puskas, J.; Howard, J.; Gan, B.S.; Reid, G. Potential application of polyisobutylene-polystyrene and a Lactobacillus protein to reduce the risk of device-associated urinary tract infections. Colloids Surf. B Biointerfaces 2003, 28, 95-105. [CrossRef]

42. Reid, G.; Tieszer, C. Use of lactobacilli to reduce the adhesion of Staphylococcus aureus to catheters. Int. Biodeterior. Biodegrad. 1994, 34, 73-83. [CrossRef]

43. Ray Mohapatra, A.; Jeevaratnam, K. Inhibiting bacterial colonization on catheters: Antibacterial and antibiofilm activities of bacteriocins from Lactobacillus plantarum SJ33. J. Glob. Antimicrob. Resist. 2019, 19, 85-92. [CrossRef] [PubMed]

44. Ifeoma, M.E.; Jennifer, U.K. Inhibition of biofilms on urinary catheters using immobilized Lactobacillus cells. Afr. J. Microbiol. Res. 2016, 10, 920-929. [CrossRef]

45. Al-Mathkhury, H.J.F.; Ali, A.S.; Ghafil, J.A. Antagonistic effect of bacteriocin against urinary catheter associated Pseudomonas aeruginosa biofilm. N. Am. J. Med. Sci. 2011, 3, 367-370. [CrossRef] [PubMed]

46. Sharma, D.; Saharan, B.S. Functional characterization of biomedical potential of biosurfactant produced by Lactobacillus helveticus. Biotechnol. Rep. 2016, 11, 27-35. [CrossRef] [PubMed] 
47. Velraeds, M.M.C.; van de Belt-Gritter, B.; Busscher, H.J.; Reid, G.; van Der Mei, H.C. Inhibition of uropathogenic biofilm growth on silicone rubber in human urine by lactobacilli-A teleologic approach. World J. Urol. 2000, 18, 422-426. [CrossRef] [PubMed]

48. Velraeds, M.M.C.; van De Belt-Gritter, B.; van Der Mei, H.C.; Reid, G.; Busscher, H.J. Interference in initial adhesion of uropathogenic bacteria and yeasts to silicone rubber by a Lactobacillus acidophilus biosurfactant. J. Med. Microbiol. 1998, 47, 1081-1085. [CrossRef] [PubMed]

49. Alves, P.; Nir, S.; Reches, M.; Mergulhão, F. The effects of fluid composition and shear conditions on bacterial adhesion to an antifouling peptide-coated surface. MRS Commun. 2018, 8, 938-946. [CrossRef]

50. Moreira, J.M.R.; Ponmozhi, J.; Campos, J.B.L.M.; Miranda, J.M.; Mergulhão, F.J. Micro- and macro-flow systems to study Escherichia coli adhesion to biomedical materials. Chem. Eng. Sci. 2015, 126, 440-445. [CrossRef]

51. Gomes, M.; Gomes, L.C.; Teixeira-Santos, R.; Pereira, M.F.R.; Soares, O.S.G.P.; Mergulhão, F.J. Optimizing CNT Loading in Antimicrobial Composites for Urinary Tract Application. Appl. Sci. 2021, 11, 4038. [CrossRef]

52. Kaur, S.; Sharma, P.; Kalia, N.; Singh, J.; Kaur, S. Anti-biofilm properties of the fecal probiotic lactobacilli against Vibrio spp. Front. Cell. Infect. Microbiol. 2018, 8, 120. [CrossRef]

53. Maldonado, N.C.; Silva De Ruiz, C.; Cecilia, M.; Nader-Macias, M.E. A simple technique to detect Klebsiella biofilm-formingstrains. Inhibitory potential of Lactobacillus fermentum CRL 1058 whole cells and products. In Communicating Current Research and Educational Topics and Trends in Applied Microbiology; Vilas, A.M., Ed.; FORMATEX: Badajoz, Spain, 2007; pp. 52-59. Available online: https: / citeseerx.ist.psu.edu/viewdoc/download?doi=10.1.1.597.5733\&rep=rep1\&type=pdf (accessed on 9 August 2021).

54. Leroy, F.; De Vuyst, L. Growth of the Bacteriocin-Producing Lactobacillus sakei Strain CTC 494 in MRS Broth is Strongly Reduced Due to Nutrient Exhaustion: A Nutrient Depletion Model for the Growth of Lactic Acid Bacteria. Appl. Environ. Microbiol. 2001, 67, 4407-4413. [CrossRef]

55. Sjollema, J.; Busscher, H.J.; Weerkamp, A.H. Deposition of oral streptococci and polystyrene latices onto glass in a parallel plate flow cell. Biofouling 1988, 1, 101-112. [CrossRef]

56. Millsap, K.W.; Reid, G.; van Der Mei, H.C.; Busscher, H.J. Adhesion of Lactobacillus species in urine and phosphate buffer to silicone rubber and glass under flow. Biomaterials 1997, 18, 87-91. [CrossRef]

57. Bujňáková, D.; Kmet', V. Functional properties of Lactobacillus strains isolated from dairy products. Folia Microbiol. 2012, 57, 263-267. [CrossRef] [PubMed]

58. Kubota, H.; Senda, S.; Nomura, N.; Tokuda, H.; Uchiyama, H. Biofilm Formation by Lactic Acid Bacteria and Resistance to Environmental Stress. J. Biosci. Bioeng. 2008, 106, 381-386. [CrossRef]

59. Jalilsood, T.; Baradaran, A.; Song, A.A.L.; Foo, H.L.; Mustafa, S.; Saad, W.Z.; Yusoff, K.; Rahim, R.A. Inhibition of pathogenic and spoilage bacteria by a novel biofilm-forming Lactobacillus isolate: A potential host for the expression of heterologous proteins. Microb. Cell Fact. 2015, 14, 96. [CrossRef]

60. Klimko, A.I.; Cherdyntseva, T.A.; Brioukhanov, A.L.; Netrusov, A.I. In vitro Evaluation of Probiotic Potential of Selected Lactic Acid Bacteria Strains. Probiotics Antimicrob. Proteins 2020, 12, 1139-1148. [CrossRef]

61. Simões, M.; Simões, L.C.; Vieira, M.J. A review of current and emergent biofilm control strategies. LWT Food Sci. Technol. 2010, 43, 573-583. [CrossRef]

62. Fernández Ramírez, M.D.; Smid, E.J.; Abee, T.; Nierop Groot, M.N. Characterisation of biofilms formed by Lactobacillus plantarum WCFS1 and food spoilage isolates. Int. J. Food Microbiol. 2015, 207, 23-29. [CrossRef]

63. Krasowska, A.; Sigler, K. How microorganisms use hydrophobicity and what does this mean for human needs? Front. Cell. Infect. Microbiol. 2014, 4, 112. [CrossRef]

64. Honey Chandran, C.; Keerthi, T.R. Probiotic potency of Lactobacillus plantarum KX519413 and KX519414 isolated from honey bee gut. FEMS Microbiol. Lett. 2018, 365, fnx285. [CrossRef]

65. Malik, S.; Petrova, M.I.; Claes, I.J.J.; Verhoeven, T.L.A.; Busschaert, P.; Vaneechoutte, M.; Lievens, B.; Lambrichts, I.; Siezen, R.J.; Balzarini, J.; et al. The highly autoaggregative and adhesive phenotype of the vaginal Lactobacillus plantarum strain cmpg5300 is sortase dependent. Appl. Environ. Microbiol. 2013, 79, 4576-4585. [CrossRef]

66. Twetman, L.; Larsen, U.; Fiehn, N.E.; Steckésn-Blicks, C.; Twetman, S. Coaggregation between probiotic bacteria and cariesassociated strains: An in vitro study. Acta Odontol. Scand. 2009, 67, 284-288. [CrossRef] [PubMed]

67. Faten, K.; Hamida, K.; Soumya, E.A.; Saad, I.S.K.; Hasna, M.; Hassan, L.; Moktar, H. Lactobacillus plantarum: Effect of a protective biofilm on the surface of olives during storage. Braz. J. Microbiol. 2016, 47, 202-209. [CrossRef] [PubMed]

68. Vertes, A.; Hitchins, V.; Phillips, K.S. Analytical challenges of microbial biofilms on medical devices. Anal. Chem. 2012, 84, 3858-3866. [CrossRef] [PubMed]

69. Percival, S.L.; Suleman, L.; Vuotto, C.; Donelli, G. Healthcare-associated infections, medical devices and biofilms: Risk, tolerance and control. J. Med. Microbiol. 2015, 64, 323-334. [CrossRef] [PubMed]

70. George, J.; Halami, P.M. Presence of extracellular DNA \& protein in biofilm formation by gentamicin-resistant Lactobacillus plantarum. Indian J. Med. Res. 2019, 149, 257-262. [CrossRef] [PubMed]

71. Muscariello, L.; Marino, C.; Capri, U.; Vastano, V.; Marasco, R.; Sacco, M. CcpA and three newly identified proteins are involved in biofilm development in Lactobacillus plantarum. J. Basic Microbiol. 2013, 53, 62-71. [CrossRef]

72. Schiøtz, H.; Tanbo, T. Postoperative voiding, bacteriuria and urinary tract infection with Foley catheterization after gynecological surgery. Acta Obstet. Gynecol. Scand. 2006, 85, 476-481. [CrossRef] [PubMed] 
73. Huang, H.; Dong, L.; Gu, L. The timing of urinary catheter removal after gynecologic surgery: A meta-analysis of randomized controlled trials. Medicine (United States) 2020, 99, e18710. [CrossRef]

74. Alessandri, F.; Mistrangelo, E.; Lijoi, D.; Ferrero, S.; Ragni, N. A prospective, randomized trial comparing immediate versus delayed catheter removal following hysterectomy. Acta Obstet. Gynecol. Scand. 2006, 85, 716-720. [CrossRef] [PubMed]

75. Glavind, K.; Mørup, L.; Madsen, H.; Glavind, J. A prospective, randomised, controlled trial comparing 3 hour and 24 hour postoperative removal of bladder catheter and vaginal pack following vaginal prolapse surgery. Acta Obstet. Gynecol. Scand. 2007, 86, 1122-1125. [CrossRef]

76. Hendren, S. Urinary catheter management. Clin. Colon Rectal Surg. 2013, 26, 178-181. [CrossRef]

77. Basbug, A.; Yuksel, A.; Ellibeş Kaya, A. Early versus delayed removal of indwelling catheters in patients after elective cesarean section: A prospective randomized trial. J. Matern. Neonatal Med. 2020, 33, 68-72. [CrossRef] [PubMed]

78. Fernandez, R.; Griffiths, R.; Murie, P. Comparison of late night and early morning removal of short-term urethral catheters. JBI Libr. Syst. Rev. 2003, 1, 1-26. [CrossRef]

79. Ahmed, M.R.; Sayed Ahmed, W.A.; Atwa, K.A.; Metwally, L. Timing of urinary catheter removal after uncomplicated total abdominal hysterectomy: A prospective randomized trial. Eur. J. Obstet. Gynecol. Reprod. Biol. 2014, 176, 60-63. [CrossRef] [PubMed]

80. Kin, C.; Rhoads, K.F.; Jalali, M.; Shelton, A.A.; Welton, M.L. Predictors of postoperative urinary retention after colorectal surgery. Dis. Colon Rectum 2013, 56, 738-746. [CrossRef]

81. Benoist, S.; Panis, Y.; Denet, C.; Mauvais, F.; Mariani, P.; Valleur, P. Optimal duration of urinary drainage after rectal resection: A randomized controlled trial. Surgery 1999, 125, 135-141. [CrossRef]

82. Dodds, L.; Lawson, P.S.; Crosthwaite, A.H.; Wells, G.R. Early catheter removal: A prospective study of 100 consecutive patients undergoing transurethral resection of the prostate. Br. J. Urol. 1995, 75, 755-757. [CrossRef]

83. Brackmann, M.; Carballo, E.; Uppal, S.; Torski, J.; Reynolds, R.K.; McLean, K. Implementation of a standardized voiding management protocol to reduce unnecessary re-catheterization-A quality improvement project. Gynecol. Oncol. 2020, 157, 487-493. [CrossRef] [PubMed]

84. Gould, C.V.; Umscheid, C.A.; Agarwal, R.K.; Kuntz, G.; Pegues, D.A. Guideline for Prevention of Catheter-Associated Urinary Tract Infections 2009. Infect Control Hosp Epidemiol. 2010, 4, 319-326. [CrossRef]

85. Tan, Y.; Leonhard, M.; Moser, D.; Ma, S.; Schneider-Stickler, B. Inhibitory effect of probiotic lactobacilli supernatants on single and mixed non-albicans Candida species biofilm. Arch. Oral Biol. 2018, 85, 40-45. [CrossRef]

86. Alexandre, Y.; Le Berre, R.; Barbier, G.; Le Blay, G. Screening of Lactobacillus spp. for the prevention of Pseudomonas aeruginosa pulmonary infections. BMC Microbiol. 2014, 14, 107. [CrossRef]

87. Lin, X.; Chen, X.; Tu, Y.; Wang, S.; Chen, H. Effect of probiotic lactobacilli on the growth of Streptococcus mutans and multispecies biofilms isolated from children with active caries. Med. Sci. Monit. 2017, 23, 4175-4181. [CrossRef]

88. Teanpaisan, R.; Piwat, S.; Dahlén, G. Inhibitory effect of oral Lactobacillus against oral pathogens. Lett. Appl. Microbiol. 2011, 53, 452-459. [CrossRef] [PubMed]

89. Maldonado-Barragán, A.; Caballero-Guerrero, B.; Lucena-Padrós, H.; Ruiz-Barba, J.L. Induction of bacteriocin production by coculture is widespread among plantaricin-producing Lactobacillus plantarum strains with different regulatory operons. Food Microbiol. 2013, 33, 40-47. [CrossRef]

90. Hasslöf, P.; Hedberg, M.; Twetman, S.; Stecksén-Blicks, C. Growth inhibition of oral mutans streptococci and candida by commercial probiotic lactobacilli-An In Vitro study. BMC Oral Health 2010, 10, 1-6. [CrossRef]

91. Vahedi Shahandashti, R.; Kasra Kermanshahi, R.; Ghadam, P. The inhibitory effect of bacteriocin produced by Lactobacillus acidophilus ATCC 4356 and Lactobacillus plantarum ATCC 8014 on planktonic cells and biofilms of Serratia marcescens. Turk. J. Med. Sci. 2016, 46, 1188-1196. [CrossRef] [PubMed]

92. Zalán, Z.; Németh, E.; Baráth, Á.; Halász, A. Influence of growth medium on hydrogen peroxide and bacteriocin production of Lactobacillus strains. Food Technol. Biotechnol. 2005, 43, 219-225.

93. Sharma, V.; Harjai, K.; Shukla, G. Effect of bacteriocin and exopolysaccharides isolated from probiotic on P. aeruginosa PAO1 biofilm. Folia Microbiol. 2018, 63, 181-190. [CrossRef] [PubMed]

94. Besser, M.; Terberger, J.; Weber, L.; Ghebremedhin, B.; Naumova, E.A.; Arnold, W.H.; Stuermer, E.K. Impact of probiotics on pathogen survival in an innovative human plasma biofilm model (hpBIOM). J. Transl. Med. 2019, 17, 1-9. [CrossRef] [PubMed]

95. Wasfi, R.; Abd El-Rahman, O.A.; Zafer, M.M.; Ashour, H.M. Probiotic Lactobacillus sp. inhibit growth, biofilm formation and gene expression of caries-inducing Streptococcus mutans. J. Cell. Mol. Med. 2018, 22, 1972-1983. [CrossRef]

96. Kang, D.K.; Oh, H.K.; Ham, J.S.; Kim, J.G.; Yoon, C.H.; Ahn, Y.T.; Kim, H.U. Identification and characterization of hydrogen peroxide-generating Lactobacillus fermentum CS12-1. Asian Australas. J. Anim. Sci. 2005, 18, 90-95. [CrossRef]

97. Kumar, S.R.; Imlay, J.A. How Escherichia coli tolerates profuse hydrogen peroxide formation by a catabolic pathway. J. Bacteriol. 2013, 195, 4569-4579. [CrossRef]

98. Imlay, J.A.; Linn, S. Mutagenesis and stress responses induced in Escherichia coli by hydrogen peroxide. J. Bacteriol. 1987, 169, 2967-2976. [CrossRef]

99. Hegde, A.; Bhat, G.; Mallya, S. Effect of exposure to hydrogen peroxide on the virulence of Escherichia coli. Indian J. Med. Microbiol. 2008, 26, 25-28. [CrossRef] 
100. Matsubara, V.H.; Wang, Y.; Bandara, H.M.H.N.; Mayer, M.P.A.; Samaranayake, L.P. Probiotic lactobacilli inhibit early stages of Candida albicans biofilm development by reducing their growth, cell adhesion, and filamentation. Appl. Microbiol. Biotechnol. 2016, 100, 6415-6426. [CrossRef]

101. Merghni, A.; Dallel, I.; Noumi, E.; Kadmi, Y.; Hentati, H.; Tobji, S.; Ben Amor, A.; Mastouri, M. Antioxidant and antiproliferative potential of biosurfactants isolated from Lactobacillus casei and their anti-biofilm effect in oral Staphylococcus aureus strains. Microb. Pathog. 2017, 104, 84-89. [CrossRef]

102. Satpute, S.K.; Mone, N.S.; Das, P.; Banat, I.M.; Banpurkar, A.G. Inhibition of pathogenic bacterial biofilms on PDMS based implants by L. acidophilus derived biosurfactant. BMC Microbiol. 2019, 19, 1-15. [CrossRef]

103. Sambanthamoorthy, K.; Feng, X.; Patel, R.; Patel, S.; Paranavitana, C. Antimicrobial and antibiofilm potential of biosurfactants isolated from lactobacilli against multi-drug-resistant pathogens. BMC Microbiol. 2014, 14, 197. [CrossRef] [PubMed]

104. Ceresa, C.; Tessarolo, F.; Caola, I.; Nollo, G.; Cavallo, M.; Rinaldi, M.; Fracchia, L. Inhibition of Candida albicans adhesion on medical-grade silicone by a Lactobacillus-derived biosurfactant. J. Appl. Microbiol. 2015, 118, 1116-1125. [CrossRef] [PubMed]

105. Satpute, S.K.; Kulkarni, G.R.; Banpurkar, A.G.; Banat, I.M.; Mone, N.S.; Patil, R.H.; Cameotra, S.S. Biosurfactant/s from lactobacilli species: Properties, challenges and potential biomedical applications. J. Basic Microbiol. 2016, 56, 1140-1158. [CrossRef] [PubMed]

106. Kim, Y.; Oh, S.; Kim, S.H. Released exopolysaccharide (r-EPS) produced from probiotic bacteria reduce biofilm formation of enterohemorrhagic Escherichia coli O157:H7. Biochem. Biophys. Res. Commun. 2009, 379, 324-329. [CrossRef] [PubMed]

107. Mahdhi, A.; Leban, N.; Chakroun, I.; Bayar, S.; Mahdouani, K.; Majdoub, H.; Kouidhi, B. Use of extracellular polysaccharides, secreted by Lactobacillus plantarum and Bacillus spp., as reducing indole production agents to control biofilm formation and efflux pumps inhibitor in Escherichia coli. Microb. Pathog. 2018, 125, 448-453. [CrossRef] [PubMed]

108. Høiby, N.; Bjarnsholt, T.; Givskov, M.; Molin, S.; Ciofu, O. Antibiotic resistance of bacterial biofilms. Int. J. Antimicrob. Agents 2010, 35, 322-332. [CrossRef]

109. Cerqueira, L.; Oliveira, J.A.; Nicolau, A.; Azevedo, N.F.; Vieira, M.J. Biofilm formation with mixed cultures of Pseudomonas aeruginosa/Escherichia coli on silicone using artificial urine to mimic urinary catheters. Biofouling 2013, 29, 829-840. [CrossRef]

110. Green, M.R.; Sambrook, J. Molecular Cloning: A Laboratory Manual; Cold Spring Harbor: New York, NY, USA, 1989.

111. Brooks, T.; Keevil, C.W. A simple artificial urine for the growth of urinary pathogens. Lett. Appl. Microbiol. 1997, 24, 203-206. [CrossRef]

112. Azeredo, J.; Azevedo, N.F.; Briandet, R.; Cerca, N.; Coenye, T.; Costa, A.R.; Desvaux, M.; Di Bonaventura, G.; Hébraud, M.; Jaglic, Z.; et al. Critical review on biofilm methods. Crit. Rev. Microbiol. 2017, 43, 313-351. [CrossRef]

113. Moreira, J.M.R.; Gomes, L.C.; Whitehead, K.A.; Lynch, S.; Tetlow, L.A.; Mergulhão, F.J. Effect of surface conditioning with cellular extracts on Escherichia coli adhesion and initial biofilm formation. Food Bioprod. Process. 2017, 104, 1-12. [CrossRef]

114. Gomes, L.C.; Moreira, J.M.R.; Miranda, J.M.; Simões, M.; Melo, L.F.; Mergulhão, F.J. Macroscale versus microscale methods for physiological analysis of biofilms formed in 96-well microtiter plates. J. Microbiol. Methods 2013, 95, 342-349. [CrossRef]

115. Heydorn, A.; Nielsen, A.T.; Hentzer, M.; Sternberg, C.; Givskov, M.; Ersboll, B.K.; Molin, S. Quantification of biofilm structures by the novel computer program COMSTAT. Microbiology 2000, 146, 2395-2407. [CrossRef] [PubMed]

116. Janczuk, B.; Chibowski, E.; Bruque, J.M.; Kerkeb, M.L.; Caballero, F.G. On the consistency of surface free energy components as calculated from contact angles of different liquids: An application to the cholesterol surface. J. Colloid Interface Sci. 1993, 159, 421-428. [CrossRef]

117. Van Oss, C.J.; Chaudhury, M.K.; Good, R.J. Monopolar surfaces. Adv. Colloid Interface Sci. 1987, 28, 35-64. [CrossRef]

118. Van Oss, C.J.; Good, R.J.; Chaudhury, M.K. Additive and nonadditive surface tension components and the interpretation of contact angles. Langmuir 1988, 4, 884-891. [CrossRef]

119. Van Oss, C.J.; Ju, L.; Chaudhury, M.K.; Good, R.J. Estimation of the polar parameters of the surface tension of liquids by contact angle measurements on gels. J. Colloid Interface Sci. 1989, 128, 313-319. [CrossRef] 